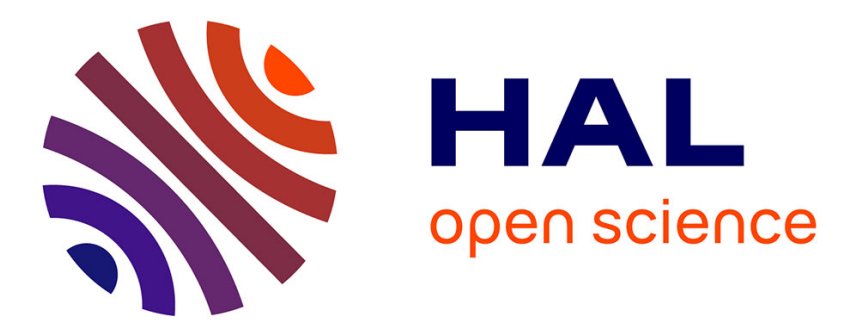

\title{
Recharge processes and vertical transfer investigated through long-term monitoring of dissolved gases in shallow groundwater
}

Véronique de Montety, Luc Aquilina, Thierry Labasque, Eliot Chatton, Ophélie Fovet, Laurent Ruiz, Elise Fourré, Jean-Raynald de Dreuzy

\section{To cite this version:}

Véronique de Montety, Luc Aquilina, Thierry Labasque, Eliot Chatton, Ophélie Fovet, et al.. Recharge processes and vertical transfer investigated through long-term monitoring of dissolved gases in shallow groundwater. Journal of Hydrology, 2018, 560, pp.275-288. 10.1016/j.jhydrol.2018.02.077 . insu01728980

\section{HAL Id: insu-01728980 \\ https://hal-insu.archives-ouvertes.fr/insu-01728980}

Submitted on 12 Mar 2018

HAL is a multi-disciplinary open access archive for the deposit and dissemination of scientific research documents, whether they are published or not. The documents may come from teaching and research institutions in France or abroad, or from public or private research centers.
L'archive ouverte pluridisciplinaire HAL, est destinée au dépôt et à la diffusion de documents scientifiques de niveau recherche, publiés ou non, émanant des établissements d'enseignement et de recherche français ou étrangers, des laboratoires publics ou privés. 


\section{Accepted Manuscript}

Research papers

Recharge processes and vertical transfer investigated through long-term monitoring of dissolved gases in shallow groundwater

V. de Montety, L. Aquilina, T. Labasque, E. Chatton, O. Fovet, L. Ruiz, E. Fourré, J.R. de Dreuzy

PII: S0022-1694(18)30159-8

DOI: https://doi.org/10.1016/j.jhydrol.2018.02.077

Reference: HYDROL 22626

To appear in: $\quad$ Journal of Hydrology

Received Date: 20 July 2017

Accepted Date: $\quad 27$ February 2018

Please cite this article as: de Montety, V., Aquilina, L., Labasque, T., Chatton, E., Fovet, O., Ruiz, L., Fourré, E., de Dreuzy, J.R., Recharge processes and vertical transfer investigated through long-term monitoring of dissolved gases in shallow groundwater, Journal of Hydrology (2018), doi: https://doi.org/10.1016/j.jhydrol.2018.02.077

This is a PDF file of an unedited manuscript that has been accepted for publication. As a service to our customers we are providing this early version of the manuscript. The manuscript will undergo copyediting, typesetting, and review of the resulting proof before it is published in its final form. Please note that during the production process errors may be discovered which could affect the content, and all legal disclaimers that apply to the journal pertain. 


\section{Recharge processes and vertical transfer investigated through long-term monitoring of dissolved gases in shallow groundwater}

V. de Montety ${ }^{1}$, L. Aquilina ${ }^{2}$, T. Labasque ${ }^{2}$, E. Chatton ${ }^{2}$, O. Fovet $^{3}$, L. Ruiz ${ }^{3}$, E. Fourré ${ }^{4}$ J.R. de Dreuzy ${ }^{2}$

${ }^{1}$ HydroSciences, UMR 5569, Université de Montpellier, Place E. Bataillon, 34095 Montpellier Cedex 5, France

${ }^{2}$ OSUR-Géosciences Rennes, Université Rennes1-CNRS, 35042 Rennes, France

${ }^{3}$ INRA, Agrocampus Ouest, UMR1069 Sol Agro et hydrosystème Spatialisation, 35000 Rennes, France

${ }^{4}$ LSCE, UMR8212, IPSL/CEA - CNRS - UVSQ, Saclay, France

*Corresponding Author:

Email: veronique.de-montety@univ-montp2.fr

Phone: +33 (2) 2323-5469

\section{Abstract}

We investigated temporal variations and vertical evolution of dissolved gaseous tracers (CFC-11, CFC-

$12, \mathrm{SF}_{6}$, and noble gases), as well as ${ }^{3} \mathrm{H} /{ }^{3} \mathrm{He}$ ratio to determine groundwater recharge processes of a shallow unconfined, hard-rock aquifer in an agricultural catchment. We sampled dissolved gas concentration at 4 locations along the hillslope of a small experimental watershed, over 6 hydrological years, between 2 and 6 times per years, for a total of 20 field campaigns. We collected groundwater samples in the fluctuation zone and the permanently saturated zone using piezometers from 5 to $20 \mathrm{~m}$ deep. The purpose of this work is $i$ ) to assess the benefits of using gaseous tracers like CFCs and SF6 to study very young groundwater with flows suspected to be heterogeneous and variable in time, ii) to characterize the processes that control dissolved gas concentrations in groundwater during the recharge of the aquifer, and iii) to understand the evolution of recharge flow processes by repeated measurement campaigns, taking advantage of a long monitoring in a site devoted to recharge processes investigation.

Gas tracer profiles are compared at different location of the catchment and for different hydrologic conditions. In addition, we compare results from CFCs and ${ }^{3} \mathrm{H} /{ }^{3} \mathrm{He}$ analysis to define the flow model that best explains tracer concentrations. Then we discuss the influence of recharge events on tracer 
concentrations and residence time and propose a temporal evolution of residence times for the unsaturated zone and the permanently saturated zone. These results are used to gain a better understanding of the conceptual model of the catchment and flow processes especially during recharge events.

Key words: $\mathrm{CFCs}, \mathrm{SF}_{6}$, noble gases, residence time, groundwater recharge processes, flow model, agricultural catchment, vadose zone

\section{Introduction}

As nitrates have become a major environmental threat in agricultural areas, numerous works evaluate mechanisms controlling $\mathrm{NO}_{3}{ }^{-}$exportation from catchment and emphasize the key role of the shallow groundwater (Böhlke and Denver, 1995; Creed and Band, 1998; Martin et al., 2006; Molenat et al., 2002). In particular, these studies show that catchment can present an important time lag in response to variation of the $\mathrm{NO}_{3}{ }^{-}$input signal. Although physical characteristics of shallow groundwater are pointed out to explain this delay, mechanisms involved are still debated. A better knowledge of this time lag, through the evaluation of the residence time of groundwater is thus crucial for managing groundwater in small agricultural catchments.

Recent results obtained using natural solutes and/or their isotopic composition as tracers, pointed out that small catchments show variable residence times that can surprisingly exceed several years (Hrachowitz et al., 2013; Kendall and McDonnell, 1998; Kirchner et al., 2001; Ruiz et al., 2002a). These methods were based on opposite trends observed between the nitrate concentrations in drainage water and in stream water (Ruiz et al., 2002a) or on spectral analysis of the input-output signal of chemical compound (Kirchner et al., 2001; Molénat et al., 2000; Neal and Kirchner, 2000) that require a high frequency monitoring of rain inputs for a long period which is rarely available.

Another approach to estimate response time to changes in agricultural practices consists in numerical modelling. Again, transit times greater than one year and up to 14 years in headwater catchments have 
been derived from mechanistic groundwater modelling (Basu et al., 2012; Martin et al., 2006; Molénat and Gascuel-Odoux, 2002) or lumped and parsimonious model and time series of nitrate concentration in streams (Fovet et al., 2015; Ruiz et al., 2002b). All these approaches use the approximation of DupuitForsheimer which reproduces the water dynamic of the catchment, but assume a perfect and instantaneous vertical mixing of groundwater neglecting vertical flows. In addition, in numerous models, individual storm events are neglected and only base flow is considered (Fovet et al., 2015; Ruiz et al., 2002b). Although these models reproduce seasonal and inter-annual nitrate variations, processes inducing temporal concentration variations at shallow depth are still poorly understood, especially after storm events.

An interesting alternative to obtain additional information on water dynamics is to analyze anthropogenic atmospheric gases. Industrial production of CFCs and $\mathrm{SF}_{6}$ started in the 1940s and 1960s respectively which makes these dating tracers suitable for the study of post-war diffuse pollution in agricultural catchments (IAEA, 2006). However, following Montreal protocol in 1987, stagnation and then decrease of atmospheric CFCs concentrations over the past two decades have induced higher uncertainties in dating of young shallow groundwater since two different recharge dates can be derived from a single gas concentration (rising or falling part of the atmospheric curve (CMDL/NOAA)). Therefore, the combined use of other dating tracers like $\mathrm{SF}_{6}$ (whose input atmospheric function is always rising) and ${ }^{3} \mathrm{H} /{ }^{3} \mathrm{He}$ (a radioactive parent/daughter clock method which does not require the knowledge of the ${ }^{3} \mathrm{H}$ input function) allows reducing uncertainties (Darling et al., 2012; Newman et al., 2010; Suckow, 2014). Another advantage of the anthropogenic gas tracers is to help conceptualizing flow and mixing processes of the studied groundwater system (Darling et al., 2012; Suckow, 2014). It is common to use lumped parameter models which fit the data to a conceptual model of defined flow, among which the most commonly used are piston (PFM), binary mixing (BMM) or exponential mixing (EM) (Maloszewski and Zuber, 1982). While each different tracer will give an apparent tracer age, stating the model used to interpret tracers concentrations will allow defining a Mean Residence Time (MRT) corresponding to the weighted average of the age distribution (Suckow, 2014). 
Numerous authors used CFCs and $\mathrm{SF}_{6}$ to obtain a better understanding of pollutant-transfer processes and to predict the most likely evolution of groundwater quality with respect to diffuse agricultural pollution (Böhlke, 2002; Gooddy et al., 2006; Katz et al., 2001; Koh et al., 2006). Gooddy et al. (2006) used the comparison of the spatial distribution of different tracers and lumped parameter models to discriminate groundwater flow regimes in different parts of the aquifer and thus improved their conceptual model. Kolbe et al. (2016) coupled groundwater modelling with CFC age dating to classify local groundwater circulation in an unconfined aquifer. Recent studies in hard-rock aquifers in Brittany provided a potential regional distribution of residence times as well as a reconstruction of $\mathrm{NO}_{3}^{-}$concentration in recharge water (Aquilina et al., 2012; Ayraud et al., 2008).

Temporal variability of residence time in the first meters of the aquifer usually receives less attention though being essential to further assess recharge processes in the critical zone. For instance, few studies focus on vertical variation of CFCs in shallow groundwater although it is a key parameter to constraint solute transfer from soil to the water table and within the aquifer (Cook et al., 1996, 1995; Le Gal La Salle et al., 2012). Moreover, no study to date investigates the temporal variability of dissolved CFCs and $\mathrm{SF}_{6}$ concentrations at a single location over several hydrologic cycles nor how robust is the conceptual model over time. Such information can be used to evaluate how residence time changes with varying recharge conditions.

In this context, the scope of this paper is $i$ ) to assess the benefits of using gaseous tracers like CFCs and SF6 to study very young groundwater with flows suspected to be heterogeneous and variable in time, $i$ ) to characterize the processes that control dissolved gas concentrations in groundwater during the recharge of the aquifer, and iii) to understand the evolution of recharge flow processes by repeated measurement campaigns, taking advantage of a long monitoring in a site devoted to recharge processes investigation (Legout et al., 2005; Rouxel et al., 2011).

To address these issues, we focus on a shallow unconfined aquifer in a small experimental catchment in Brittany (West of France) where flow processes and nitrate dynamic have been extensively studied giving a strong knowledge on water quality (Martin et al., 2006, 2004; Rouxel et al., 2011; Ruiz et al., 2002b). 
We investigate dissolved CFCs and $\mathrm{SF}_{6}$ gases concentrations during 6 hydrological cycles at different depths ranging from 4 to $20 \mathrm{~m}$ below ground level. Gas tracer profiles are compared at different locations of the catchment and for different hydrologic conditions. We compare CFCs and ${ }^{3} \mathrm{H} /{ }^{3} \mathrm{He}$ apparent ages and discuss flow model that best explains tracer concentrations and origin of apparent age discrepancies between age dating tracers. Then we discuss the influence of recharge events on tracer concentrations and residence time and propose a temporal evolution of residence times for the unsaturated zone and the permanent groundwater of the catchment. These results are used to gain a better understanding of the conceptual model of the catchment and flow processes especially during recharge events.

The originality of this work is thus $i$ ) to use a detailed analysis of long-term time-series of dissolved gas tracers (CFC-11, CFC-12, $\mathrm{SF}_{6}$ as well as recharge temperature and excess air deduced from noble gases concentrations); ii) to investigate their temporal evolution in vertical profiles ranging from 0 to $20 \mathrm{~m}$ below ground level.

\section{Methods}

\subsection{Site description}

Kerrien site is a small experimental catchment $\left(0.095 \mathrm{~km}^{2}\right)$ located closed to the sea in an intensive agricultural area south-west of Brittany, France (Figure 1). This site is part of the French observatory network RBV (http://rnbv.ipgp.fr/) and belongs to the Environmental Research Observatory AgrHys (http://www6.inra.fr/ore_agrhys_eng/) devoted to studies of response times of hydro-chemical fluxes under changing agriculture.

The study site is representative of hard rock catchments. It has been previously described by Martin et al. (2004). The fissured and fractured granitic bedrock is overlain by a regolith of an estimated average thickness of 20m (Legchenko et al., 2004 in Martin et al., 2004). The regolith constitutes the main 
unconfined, shallow aquifer, with a hydraulic conductivity ranging from $9.10^{-6}$ to $5.10^{-4} \mathrm{~m} \cdot \mathrm{s}^{-1}$ and a total porosity of $0.4 \%$ (Rouxel et al., 2012). The hillslope of the catchment shows a topographic gradient varying from $14 \%$ upslope to $5 \%$ downslope. Groundwater table roughly follows the topographic slope. It comes up to the ground level downslope while upslope, a zone of about $2 \mathrm{~m}$ thickness remains permanently unsaturated. The surface runoff is negligible on the hillslopes and the shallow groundwater provides most of the stream flow with a base flow index about $90 \%$ (Ruiz et al., 2002b). Groundwater table level displays large seasonal fluctuations ranging from less than one meter downslope to 4 to 6 meters upslope.

The climate is oceanic. Mean annual rainfall for the period $2003-2010$ was $1033 \pm 186 \mathrm{~mm}$, slightly lower than the mean annual rainfall of $1185 \mathrm{~mm}$ over the decade 1992-2002 (Molenat et al., 2008). The interannual variability is large with rainfall in $2005(616 \mathrm{~mm})$ being half of rainfall in $2010(1220 \mathrm{~mm})$. Mean annual PET is less variable with a mean annual value of $704 \pm 19 \mathrm{~mm}$. The average maximum and minimum monthly rainfall occurs in November and September (143mm and $47 \mathrm{~mm}$ respectively). Recharge period extends from November to March but it can vary slightly depending on the yearly rainfall pattern.

Groundwater chemical composition has been extensively studied since the early 1990s in this site (Martin et al., 2004; Martin et al., 2006; Molenat et al., 2008; Rouxel et al., 2011, and references therein). Groundwater has been affected by diffuse pollution due to intensive agriculture and breeding over the last 40 years (Ruiz et al., 2002b). The groundwater display high nitrate concentrations upslope and below $2 \mathrm{~m}$ downslope (Molenat et al., 2008). Nitrate fluxes and seasonal variability have been analyzed in previous works (Martin et al., 2004; Martin et al., 2006; Rouxel et al., 2011; Ruiz et al., 2002b).

The site was instrumented since the early 1990s. In December 2004, 42 nested piezometers from 3 to $15 \mathrm{~m}$ depth were drilled at three different positions along the slope. They were organized in two transects along the hillslope, each containing 3 nests of 7 piezometers (Figure 1). The shallow wells (3 and $4 \mathrm{~m}$ ) were screened on the last $50 \mathrm{~cm}$ only and the other ones $(5,6,8,10$ and $15 \mathrm{~m})$ were screened on the last meter, 
allowing precise sampling at the different depths (Rouxel et al., 2011). This study focuses on the first transect H, J, L. After the installation of the piezometers, the catchment received low input of mineral fertilizer or manure (Rouxel et al., 2011). In addition, we sampled a 20m deep piezometer (F), screened between 19m and 20m, and drilled in 2001 upslope near the catchment divide (Martin et al., 2004).

\subsection{Sampling and chemical analyses}

\section{Field Sampling}

Groundwater samples were collected from the piezometers at the 3 nests $\mathrm{H}, \mathrm{J}, \mathrm{L}$ at depth ranging from 5 to $15 \mathrm{~m}$ and from the piezometer $\mathrm{F}$ at $20 \mathrm{~m}$ depth (Table 1 ). Twenty sampling surveys have been realized during the monitoring period covering 6 hydrological cycles. More than 170 samples were collected for CFCs analyses (2005 to 2010) and 110 samples for $\mathrm{SF}_{6}$ (2006 to 2010). Noble gases have been sampled since 2007. The number of samples per piezometer varied from 3-5 samples for shallow piezometers (5m) to up to 16 samples in the permanent groundwater $(10-15 \mathrm{~m})$.

Groundwater samples were collected with a submersible MP1 Grundfos pump connected to a nylon tubing after stabilization of their physico-chemical parameters (temperature, specific conductivity, $\mathrm{pH}$ and ORP). CFCs and $\mathrm{SF}_{6}$ samples were collected without atmospheric contact in glass ampoules of $20 \mathrm{ml}$ (CFCs) and 500ml $\left(\mathrm{SF}_{6}\right)$ closed with two PTFE three-way valves for samples before March 2007 and in stainless-steel ampoules of $40 \mathrm{ml}(\mathrm{CFCs})$ and $300 \mathrm{ml}\left(\mathrm{SF}_{6}\right)$ closed with two stainless-steel three-way valves since then. Noble gases were sampled in $500 \mathrm{ml}$ glass bottles after purging three times the bottle volume under water in a bucket. Bottles were closed with rubber caps and sealed with metal ring. All sampling ampoules were rinsed 3 times before collecting water. Physico-chemical parameters were simultaneously measured and major elements collected for each sampling period. Samples were filtered in the field $(0.45 \mu \mathrm{m})$ and kept refrigerated prior to analyses. In addition, for four sampling campaigns (June07, Dec08, Apr and Oct09) specific sampling was dedicated to ${ }^{3} \mathrm{H} /{ }^{3} \mathrm{He}$ analyses, representing 39 samples. Samples for ${ }^{3} \mathrm{H}$ analyses were collected in $500 \mathrm{ml}$ Pyrex bottles, baked at $75^{\circ} \mathrm{C}$ and pre-filled with argon. 
Samples for He analyses were collected using standard refrigeration grade $3 / 8$ " copper tubes sealed by metal clamps at both ends.

Water table levels were recorded at $15 \mathrm{~min}$ intervals in the deepest piezometers (H15, J15, and L15). Precipitation, and the parameters required to calculate potential evapotranspiration by the Penman formula (mean temperatures, mean relative humidity, global radiation, wind velocity) were recorded at hourly frequency $700 \mathrm{~m}$ away from the study site.

\section{Lab analyses}

Anthropogenic and noble gases analyses were realized in Geosciences Rennes laboratory as detailed in Labasque et al. (2008). CFCs and $\mathrm{SF}_{6}$ were extracted following the purge and trap method and quantified by gas chromatography with electron capture detection. The analyses are within a precision of $3 \%$ for CFC-11 and CFC-12 and 5\% for CFC-113 and SF . Noble gases (Ne, Ar) and $\mathrm{N}_{2}$ were extracted by headspace and measured by gaz chromatography with a catharometer detector ( $\mu$ GC 3000 - SRA) with a precision of 5\%. Major anions $\left(\mathrm{Cl}^{-}, \mathrm{SO}_{4}^{-}, \mathrm{NO}_{3}{ }^{-}\right)$were analyzed with an automated Dionex DX-100 Ion Chromatograph with a precision better than $5 \%$. Tritium and noble gas isotopes $\left({ }^{3} \mathrm{He},{ }^{4} \mathrm{He}\right.$ and $\left.{ }^{20} \mathrm{Ne}\right)$ were analyzed at LSCE (Saclay, France) with a MAP-215-50 mass spectrometer using routine procedures (Jean-Baptiste et al., 2010, 1992). ${ }^{4} \mathrm{He}$ and ${ }^{20} \mathrm{Ne}$ isotopes were measured to assess excess air and radiogenic contribution and derive the tritiogenic ${ }^{3} \mathrm{He}$ component. Dissolved $\mathrm{He}$ and $\mathrm{Ne}$ were first extracted under vacuum into sealed glass tubes. The measurements were calibrated with an air standard. The water for ${ }^{3} \mathrm{H}$ determination was degassed and stored to allow for ${ }^{3} \mathrm{He}$ ingrowth before mass spectrometry measurement. Mean uncertainty is about $5 \%$ for ${ }^{3} \mathrm{H}$, and between $1 \%$ and $1.5 \%$ for He and Ne isotopes. 


\subsection{Data analyses}

Uncertainty of apparent CFCs and SF6 age determination relies first on the calculation of atmospheric mixing ratio (pptv) in recharge water. This calculation requires the groundwater recharge elevation and the recharge temperature. The studied catchment can be assumed as a simple homogeneous system with an average elevation of $30 \mathrm{~m}$ above sea level and low topographic variation within the catchment area $(<$ $10 \mathrm{~m}$ ). Influence of recharge elevation is reported to be small for elevation variation below 1000m (IAEA, 2006), the recharge elevation has thus a minor impact in CFCs determination in this study. The recharge temperature can be assumed to be close to the mean annual air temperature $\pm 1^{\circ} \mathrm{C}$ (Cook et al., 2006; Herzberg and Mazor, 1979). During the monitoring period, the mean annual air temperature is $11.9 \pm 0.4^{\circ} \mathrm{C}$, in good accordance with previous work $\left(11.4^{\circ} \mathrm{C}\right.$; Ruiz et al., $\left.2002 \mathrm{~b}\right)$, with mean monthly temperature ranging from $6.4^{\circ} \mathrm{C}$ in February to $16.7^{\circ} \mathrm{C}$ in July.

$\mathrm{Ne}$ and Ar concentrations were also used to estimate Noble Gaz recharge Temperature (NGT) as well as excess air. Two methods were used: (i) Ar/Ne chart (Heaton and Vogel, 1981) (ii) an inversion model (Aeschbach-Hertig et al., 2000; Stute et al., 1995) using, Ne, Ar and N2 to compute the recharge parameters including recharge temperature, excess air and fractionation using either a closed equilibrium or a partial re-equilibration model (Chatton et al., 2016). A comparison of the three computations showed only a slight difference of recharge temperature $\left(0.6^{\circ} \mathrm{C}\right)$. Therefore, the closed equilibrium model has then been used.

At the water table $(6 \mathrm{~m})$, water temperature varies between $11 \pm 1^{\circ} \mathrm{C}$ in March to $13 \pm 1^{\circ} \mathrm{C}$ in the period October-December. Mean NGT is about $10^{\circ} \mathrm{C}$ with variations between $7.5^{\circ} \mathrm{C}$ and $17^{\circ} \mathrm{C}$ with most of the data comprise between $7^{\circ} \mathrm{C}$ and $12.5^{\circ} \mathrm{C}$. There is a strong variation of NGT $\left( \pm 3^{\circ} \mathrm{C}\right)$ compared to water temperature in wells with numerous data below the lower measured water temperature. When considering impact of recharge temperature on calculated CFCs ratios, it appears that the use of low temperature value $\left(7^{\circ} \mathrm{C}\right)$ increases solubility and then decreases CFCs ratios for the same concentration in water. As a consequence, permanent groundwater shows older apparent tracer ages, (162pptv -26yrs at $7^{\circ} \mathrm{C}$ compare 
to $214 \mathrm{pptv}-20 \mathrm{yrs}$ at $11.9^{\circ} \mathrm{C}$ for $\mathrm{CFC}-11$ ) and ratios in shallow water become too low for estimating age on the recent part of the atmospheric curve. Finally, we do not have NGT for all the dataset since noble gas measurement started only in 2007. For all these reasons and to not introduce a bias in the CFCs ratios calculation at the different sampling date, mean annual air temperature has been used for CFCs and SF6 ratios calculation. NGT temperature estimated with only two noble gases ( $\mathrm{Ne}$ and $\mathrm{Ar}$ ) gives too large uncertainties. $\mathrm{Kr}$ and Xe determination should be developed. N2 utilization in this agricultural watershed should also introduce uncertainties on NGT. The sensitivity of apparent age determination to a variation of $1^{\circ} \mathrm{C}$ of recharge temperature is small. The sensitivity for $\mathrm{CFC}-11$ is less than 2 years. ${ }^{\circ} \mathrm{C}^{-1}$ for recharge before 1994 and 5 years. ${ }^{\circ} \mathrm{C}^{-1}$ in average for recharge after 1994. For CFC-12, only recharge prior to 2002 were determined with apparent ages precisions about 2 years. ${ }^{\circ} \mathrm{C}^{-1}$.

$\mathrm{SF}_{6}$ data were corrected for the influence of excess air using $\mathrm{Ne}$ concentrations according to the methodology proposed by Aeschbach-Hertig (2004). For sample collected before the first noble gases sampling, a mean value of excess air was calculated for each piezometer using samplings from 2007 to 2010. The influence of excess air was found to be negligible for CFCs and has thus been neglected.

The calculated mixing ratios were then compared to atmospheric mixing curves to estimate the apparent age of water. Considering the rural location of the study site, no local contaminations were expected (Ayraud et al., 2008). The CMDL/NOAA values were thus used as input function for CFCs and $\mathrm{SF}_{6}$. CFC-11 concentrations and to a lesser extent CFC-12 concentrations fall close to the maximum atmospheric air concentration due to the relatively short residence time of water in this shallow aquifer. Consequently, for samples with concentration ranging from 240pptv to 272pptv for CFC-11 and from 530pptv to 546pptv for CFC-12, 2 apparent recharge dates could be attributed (before or after the atmospheric maximum value). If all samples had been attributed to the same portion of the atmospheric curve, the same range of apparent age would have been attributed to shallow (4 to $6 \mathrm{~m}$ ) and deep samples. Moreover, when considering apparent recharge date before the maximum atmospheric concentration for samples from 6 to 10m, a general decrease of apparent age with depth was observed. These two results 
were found unrealistic and were in strong disagreement with observed $\mathrm{Cl}^{-}$evolution and prior knowledge on the hydrogeological context. To decide which portion of the atmospheric curve should be used, we used the vertical evolution of ${ }^{3} \mathrm{H} /{ }^{3} \mathrm{He}$ age. ${ }^{3} \mathrm{H} /{ }^{3} \mathrm{He}$ analysis show low age for samples at $6 \mathrm{~m}(<2$ years $)$ and a general increase of age with depth $(\sim 0.75 \mathrm{yrs} / \mathrm{m})$. Consequently, recharge dates were determined using the portion of the atmospheric curve before the maximum for deep groundwater $(15-20 \mathrm{~m})$ and the portion of the atmospheric curve after the maximum for the other depth $(10,8,6,5 \mathrm{~m})$.

The ${ }^{3} \mathrm{H} /{ }^{3} \mathrm{He}$ age was computed using usual methodology (Schlosser et al., 1989). The ${ }^{3} \mathrm{H} /{ }^{3} \mathrm{He}$ age $\tau$ is defined as $\tau=\lambda^{-1} \operatorname{Ln}\left(1+{ }^{3} H e_{t r i} l^{3} H\right)$, where $\lambda$ is the decay constant for tritium; ${ }^{3} H$ is the measured tritium concentration expressed in Tritium Units (TU) and ${ }^{3} \mathrm{He}_{t r i}$ is the fraction of the total ${ }^{3} \mathrm{He}$ produced by ${ }^{3} \mathrm{H}$ decay. ${ }^{3} \mathrm{He}_{t r i}$ is the difference between the measured ${ }^{3} \mathrm{He}$ concentration and the sum of ${ }^{3} \mathrm{H}$ concentrations from atmospheric $\left({ }^{3} \mathrm{He} e_{a t m}\right)$ and terrigenic $\left({ }^{3} \mathrm{He}\right.$ ter $)$ origins. The atmospheric component reflects both the gas dissolved at the solubility equilibrium and an excess air component as ubiquitously observed in groundwater (Kipfer et al., 2002 and references therein). ${ }^{3} H e_{a t m}$ and ${ }^{3} H e_{t e r}$ can be deduced from the measured concentrations of $\mathrm{He}$ and $\mathrm{Ne},{ }^{4} \mathrm{He} e_{\text {meas }}$ and ${ }^{20} \mathrm{Ne} e_{\text {meas }}$, using the following set of equations:

$-{ }^{4} \mathrm{He}_{\text {atm }}={ }^{20} \mathrm{Ne}_{\text {meas }} \times \alpha$, where $\alpha$ is the solubility of ${ }^{4} \mathrm{He} /{ }^{20} \mathrm{Ne}$ at the recharge temperature $\left(12 \pm 1{ }^{\circ} \mathrm{C}\right)$,

$-{ }^{3} H e_{a t m}={ }^{4} \mathrm{He}_{\text {atm }} \times \mathrm{R}_{\mathrm{a}} \times 0.985$, with the atmospheric ${ }^{3} \mathrm{He} /{ }^{4} \mathrm{He}$ ratio $\mathrm{R}_{\mathrm{a}}=1.38 \times 10^{-6}$,

$-{ }^{3} H e_{\text {ter }}=\left({ }^{4} H e_{\text {meas }}-{ }^{4} H e_{\text {atm }}\right) \times \mathrm{R}_{\mathrm{ter}}$ where $\mathrm{R}_{\mathrm{ter}}$ stands for the isotopic ratio of radiogenic helium production in rocks, set in this work at the typical value of $2.0 \pm 0.5 \times 10^{-8}$.

The overall uncertainty in the apparent ${ }^{3} \mathrm{H} /{ }^{3} \mathrm{He}$ ages is about 3 years in the case of this study.

\section{Results}

\subsection{Hydrodynamic and chemical characterization of the study period}

\section{$\underline{\text { Hydrological conditions }}$}


Contrasted hydrological conditions were observed leading to differentiate two hydrological periods and one particular recharge event on the whole data set. The two first cycles (2005 and 2006) have precipitations below the mean inter-annual value (Figure 2A) and correspond to a dry period. During this period, daily water table variations are low even during the recharge period. From 2007 to 2010, precipitations are higher or equal to the inter-annual value and characterize a humid period. Water table shows high daily variations in the early stage of the recharge periods (Figure 2C). In particular, the hydrological year 2007 is characterized by intense precipitation inducing a very sharp increase of water table at the beginning of the recharge period (fall 2006). However, according to Ruiz et al. (2002b), on average, the fast flow associated with such storm events represents only $10 \%$ of the total annual flux.

Groundwater level shows high amplitude of seasonal variations. Upslope, close to the watershed divide, (nest H; Figure 2B), water table depth varies from 5.5 - 6m to 2 - $3 \mathrm{~m}$ during the hydrologic cycle. The permanently unsaturated zone is thus about $3 \mathrm{~m}$ thick. The aquifer remains permanently saturated up to $6 \mathrm{~m}$ below ground level. Water table level is slightly deeper downslope (nest $\mathbf{J}$ and L; Figure 2B) but fluctuations observed upslope (nest $\mathrm{H}$ ) and downslope (L) show a similar pattern. Midslope nest (J) shows a slightly different pattern with sharper fluctuations and the deepest water table level at the end of the recession period reflecting lower permeability in this area.

\section{Influence of recharge and recession periods on groundwater chemistry}

As previously reported $\mathrm{Cl}^{-}$and $\mathrm{NO}_{3}{ }^{-}$show important annual variations (Figure $2 \mathrm{C}, \mathrm{NO}_{3}{ }^{-}$not shown) which contrast with the relative stability of the inter-annual values (Legout et al., 2007; Ruiz et al., 2002b). During the early stage of recharge periods shallow piezometers show a sharp decrease of $\mathrm{Cl}^{-}$ concentrations particularly visible for the recharge event of fall 2006. Such $\mathrm{Cl}^{-}$drops indicate rapid circulations through the vadose zone inducing important dilution effect down to $6 \mathrm{~m}$ depth. Such events can be characterized as "by-pass" events. After 2007, the lack of data for these piezometers does not allow the observation of a similar evolution. However, a similar sharp decrease has been recorded on conductivity (not shown), confirming the dilution effect for early stages of recharge period. Then, after 
2006, $\mathrm{Cl}^{-}$variations follow water table fluctuations: during second stage of recharge period, $\mathrm{Cl}^{-}$ concentration increases when water level increases and reaches the highest $\mathrm{Cl}^{-}$concentration at the end of the recharge periods (Figure 2C). This variation has been previously suggested to be related to soil and regolith matrix contribution (Legout et al., 2007).

During recession period, $\mathrm{Cl}^{-}$concentration decreases following water table decreases and reaches the lowest $\mathrm{Cl}^{-}$concentration of the cycle. $\mathrm{Cl}^{-}$variations are observed both in unsaturated and saturated zone down to $15 \mathrm{~m}$ but the variations are larger for shallow piezometers. In contrast, the deepest piezometer $(\mathrm{F}$; $20 \mathrm{~m}$ depth), which presents the lowest $\mathrm{Cl}^{-}$concentration, shows almost no annual variation. This evolution shows that the deep part of the saturated zone is not affected by preferential vertical flow path and thus, its chemical composition can be considered as representative of the groundwater end-member to interpret the highly variable chemical composition of shallow piezometers. As the dynamic of $\mathrm{Cl}^{-}$ concentration is particularly visible during the 2006-2007 cycle, we will therefore focus on this cycle.

\subsection{Recharge temperature and excess air in groundwater}

Figure 3 shows the recharge temperature and excess air derived from the $\mathrm{Ne}, \mathrm{Ar}$ and $\mathrm{N}_{2}$ concentrations. Recharge temperatures range from 7.5 to $17^{\circ} \mathrm{C}$ with most of the data between 7.5 and $12.5^{\circ} \mathrm{C}$ i.e. with a wide range reflecting the soil temperature along the whole year. Excess air ranges from 0 to $0.02 \mathrm{~cm}^{3} \mathrm{STP} \cdot \mathrm{g}^{-1}$. The results show small variations with depth. Shallow piezometers tend to have low excess air and slightly higher recharge temperature while at 15 and $20 \mathrm{~m}$ depth, excess air is slightly higher. However, a clear correlation with the hydrological regime could be observed. There is a global positive correlation between temperature and excess air, especially for samples from a recharge or discharge period. In general, samples with high NGT and low EA correspond at the end of recharge process (black squares; Fig 3; Figure2: March07, March08, and April09). 


\subsection{Gas tracer distribution in groundwater}

Table 1 summarizes the data obtained for CFC-11, CFC-12, $\mathrm{SF}_{6}$ and ${ }^{3} \mathrm{H} /{ }^{3} \mathrm{He}$ per nest and per depth. All CFCs concentrations are relatively high in the aquifer, close to atmospheric maximum. CFC-11 concentrations range from $180 \mathrm{pptv}$ to $297 \mathrm{pptv}$ with an average concentration of $252 \mathrm{pptv}$. These values indicate young groundwater $(<25 \mathrm{yrs}$ of apparent age) in good agreement with the small size of this unconfined aquifer. The relative standard deviation (stdv/mean) is about $10 \%$ but tends to be lower for deep piezometer at the head of the catchment (piezometer F) indicating a higher stability of concentrations with depth. CFC-12 concentrations range from 241 to 571 pptv with an average concentration of 492pptv. The relative standard deviation is slightly higher namely for H8 and H15 (Table 1). After correction from excess air, $\mathrm{SF}_{6}$ concentrations are almost always above saturation with an average value of 7.4pptv (compared to atmospheric value of 6.99pptv in 2010). These high values most probably reflect $\mathrm{SF}_{6}$ lithogenic production within the weathered part of the aquifer. This interpretation is supported by batch leaching experiments of the Kerrien alterites that showed high $\mathrm{SF}_{6}$ fluxes derived from the rock (Aquilina et al., 2010).

\section{Spatial distribution}

CFC-11 and CFC-12 mixing ratios show similar vertical profiles for the different nests (Figure 4) suggesting that no clear evolution of the flow regime can be observed from upslope to downslope location of the catchment. CFC-11 vertical profile shows a decreasing concentration from 4 to $6 \mathrm{~m}$ depth with the lowest concentrations observed at $6 \mathrm{~m}$ depth. Then concentrations slightly increase up to $15 \mathrm{~m}$. These variations are the highest for nest $\mathrm{H}$. At the opposite, nest $\mathbf{J}$ shows the most constant vertical profile both in CFC-11 and CFC-12. As the scope of the paper is to give a better knowledge of recharge processes, we will then focus on detailed variations at nest $\mathrm{H}$. To understand these profiles variation, it is necessary to have a closer look on the data evolution with time. 


\section{Temporal variation}

The long term monitoring (Figure 2D) showed 2 clear trends in relation with the hydrologic condition. During the first dry cycles, in nest $\mathrm{H}$, dissolved gases showed a general increase of their concentrations which is particularly pronounced from March06 to Sept06 (Figure 2D). Moreover, several data present value above the atmospheric maximum. The occurrence of these high value disappeared after 2007. During the humid period, from 2007 to 2010 concentrations stabilize more or less between present atmospheric concentration and maximum concentrations with a slight increase trend for the deepest piezometer $(20 \mathrm{~m})$. Two important decreases of CFC-11 values were observed during recharge periods of January 2007 and December 2008. In detail, this observation leads to distinguish vertical patterns of recharge and recession periods (Figure 5).

(1) During water table decrease (Apr and Ju106, March07, Apr09, Oct09 and March10), CFC-11 profiles were highly homogeneous with values ranging from 240 to $275 \mathrm{pptv}$ (Figure 5B). Variation of CFC-11 concentration at the same depth was found to be very low. Two campaigns (May05 and Sept06) showed values above atmospheric maximum. The origin of these high values is not fully understood yet.

(2) During recharge event, CFC-11 profiles showed lower values and a higher variability especially in the water table fluctuation zone (4 to $8 \mathrm{~m}$; Figure 5A). For instance, the particular recharge event of January 2007 is marked by a sharp decrease of CFC-11 concentrations for all nests and depth down to $15 \mathrm{~m}$, correlated to the fast water table increase and $\mathrm{Cl}^{-}$decrease (Figure 2C). The lowest gases values were observed at $6 \mathrm{~m}$ depth. The lack of gas data at $20 \mathrm{~m}$ depth does not allow concluding on the maximum depth of influence. This concentrations fall was also noticeable for CFC-12 in a lesser extent, but not for CFC-113. A similar phenomenon was recorded during the recharge period of 2008 but to a lesser extent. This observation could explain the difference of global CFCs vertical profiles (Figure 4).

\section{$\underline{\text { Apparent age and flow model distribution }}$}


Mean apparent ${ }^{3} \mathrm{H} /{ }^{3} \mathrm{He}$ ages per depth range from 1.3 to 10.3 years with standard deviation ranging from 0.8 to 2.9 based on replicate samples (Table 1). Figure 6A compares apparent ${ }^{3} \mathrm{H} /{ }^{3} \mathrm{He}$ ages and CFC-11 ages derived from piston flow model. Although CFCs and ${ }^{3} \mathrm{H} /{ }^{3} \mathrm{He}$ ages present discrepancies, ages given by the 2 methods are in the same order of magnitude $(<25 \mathrm{yrs})$ and both present a general increase with depth. In detail, results show that for shallow depth down to $10 \mathrm{~m}$, most of CFC-11 provide similar or younger values than ${ }^{3} \mathrm{H} /{ }^{3} \mathrm{He}$, lower than 5yrs (Figure 6). On the contrary, for the 15-20m depth, CFC-11 apparent ages appear older than ${ }^{3} \mathrm{H} /{ }^{3} \mathrm{He}$ (about 20yrs for CFC-11 vs $5-12 \mathrm{yrs}$ for ${ }^{3} \mathrm{H} /{ }^{3} \mathrm{He}$ ) and a gap of CFC-11 ages can be observed between 12 and 18yrs. Part of this discrepancy can be due to the use of the piston flow model. At $15-20 \mathrm{~m}$, as apparent ${ }^{3} \mathrm{H} /{ }^{3} \mathrm{He}$ is about 10 years old, CFC data fall at the maximum of the atmospheric mixing curves, increasing uncertainty in apparent age determination. The systematic use of the rising part of the atmospheric curve could have biased old the apparent CFC piston ages.

Measured concentrations of CFC-11 and CFC-12 were compared with theoretical curves of different lumped parameter models (piston flow PFM, exponential mixing EMM, and binary mixing BMM; Figure 7). Data fit in the higher part of the curves again indicating young groundwater of less than 25yrs. Numerous points appeared out of the curves indicating discrepancies between the 2 tracers. The CFC-11 values above the PFM curve correspond to the 2 first years of sampling that showed data above the atmospheric maximum indicating CFC-11 contamination. In contrast, low CFCs concentrations obtained during the special recharge event of January 2007 (and December 2008 at a lower degree) are shifted down and plotted out of the model curves (Figure 7B). This is particularly visible for shallow depth $(4,5-$ $6 \mathrm{~m}$, Figure 7A). The other groundwater samples show mixed characteristics with data however mostly limited by a mixing line of present water and water recharge in 1988 (20yrs old). Taking into account the uncertainties, two main models explain most of the data: a piston model and an exponential mixing model.

We calculate CFC-11 MRT using an exponential model (EM). When no ages could be determined by EM (concentration higher than the maximum of the exponential curve), ages were derived from PFM. For 
young samples, similar ages were obtained with both models. For samples from $20 \mathrm{~m}$ only exponential ages could be obtained. Finally, recession periods were better explained by piston flow model.

The resulted MRT is presented versus ${ }^{3} \mathrm{H} /{ }^{3} \mathrm{He}$ apparent age in Figure $6 \mathrm{~B}$ and C. A better agreement of CFC MRT and ${ }^{3} \mathrm{H} /{ }^{3} \mathrm{He}$ ages is obtained (Figure 6B), with most of CFC MRT below $12 \mathrm{yrs}$, in better accordance with ${ }^{3} \mathrm{H} /{ }^{3} \mathrm{He}$ apparent age. In particular, MRT from recession periods were in good agreement with ${ }^{3} \mathrm{H} /{ }^{3} \mathrm{He}$ apparent age (Apr09, Oct09; Figure 6C). However, some CFC MRT, still appear older than ${ }^{3} \mathrm{H} /{ }^{3} \mathrm{He}$ apparent age, with no apparent correlation with depth. When looking at the hydrological period (Figure 6C), it appears that CFC MRT that are older than 3H/3He age correspond to the Dec08 recharge event. Similarly, CFC MRTs from recharge events of Jan07 appear still older than average apparent ${ }^{3} \mathrm{H} /{ }^{3} \mathrm{He}$ ages (about $15 \mathrm{yrs}$ even at shallow depth). For these events the type of lumped parameter model used to obtain MRT is not the origin of the discrepancy.

\section{Discussion}

\subsection{Uncertainty in gas concentration estimation}

The results show that ages obtained by ${ }^{3} \mathrm{H} /{ }^{3} \mathrm{He}$ and CFCs methods are in the same order of magnitude. Nevertheless, like in other studies combining these 2 age tracers, some discrepancies are observed (Happell et al., 2006; Kaown et al., 2009; Martin et al., 2016; Rademacher et al., 2001). Younger ${ }^{3} \mathrm{H} /{ }^{3} \mathrm{He}$ ages could be attributed to diffusive loss of ${ }^{3} \mathrm{He}$ to the atmosphere at times of low water table (Solomon et al. 1993, in Cook et al., 1995; Delbart et al., 2016; Martin et al., 2016; Rademacher et al., 2001). This would "reset" the ${ }^{3} \mathrm{He} /{ }^{3} \mathrm{H}$ clock inducing younger ages than CFCs ages (Cook et al., 1996). Noble gases are more prone to re-equilibration than CFCs because of their higher diffusivity (Han et al., 2006). This phenomenon could be enhanced by the thin vadose zone of the study site. In this study, CFCs retardation effect within the unsaturated zone would probably have low impact due to the low thickness of the 
permanently unsaturated zone (few meters thick) (Cook et al., 2006). In contrast, matrix diffusion processes between preferential flow path and matrix could cause discrepancy between the different tracers as they do not have the same aqueous diffusion coefficient (Cook et al., 2006). This phenomenon could explain why the apparent age derived from CFCs is higher than the water age derived from ${ }^{3} \mathrm{H} /{ }^{3} \mathrm{He}$.

Finally, the discrepancy could result from equilibration temperature that induced uncertainty in CFCs age calculation with older CFCs ages if recharge temperature is set too high. In this study we found differences in recharged temperature derived from NGT and Mean Annual Air Temperature. Such discrepancy has already been reported by Hall et al. (2005). They show that the lower NGTs compared to MAAT could reflect potential degassing or the time necessary for the waters to equilibrate. This is probably the case for groundwater showing little excess air. In both cases as observed by Hall et al. (2005), NGTs may be influenced by hydrological conditions. Such influence may explain the correlation between excess air and recharge temperature as well as the sampling-time, i.e. hydrological conditions dependency. This result requires further research but supports the interpretation of gas data as tracers of recharge processes.

\subsection{Influence of position along the hillslope}

Contrary to studies in a similar context (Gooddy et al., 2006; Newman et al., 2010), gas concentrations do not indicate clear variations of flow regime down gradient through the catchment (Figure 4). This is consistent with the conclusion of a recent modeling study in a similar catchment (Molénat et al., 2013) where simulated CFCs groundwater mixing ratios were found not sensitive to the position along the hillslope in the range of the simulated MRT. In detail, the highest CFC vertical variations for nest $\mathrm{H}$ indicate a higher sensitivity to infiltration. Nest L appears to have similar behavior than nest $\mathrm{H}$ while nest J shows more homogeneous concentration with depth suggesting better permeability of the system. This slightly different physical property in nest $\mathrm{J}$ induces a lower influence of rapid infiltration which supports previous observations on spatial variation of water quality along the hillslope (Rouxel et al., 2011). 


\subsection{Influence of hydrologic condition on CFCs variability}

At short time scale, the results show the influence of the sampling period on CFCs variability in groundwater. During low flow, there are small variations between different sampling periods (example of March07, March10 and Apr09) proving that one single time field sampling can be sufficient in most of cases. However, in this shallow aquifer, results show that recharge events have a strong impact on CFCs concentrations.

\section{Processes influencing concentrations during beginning and end of recharge}

The most representative example is the sampling during the recharge event of January 2007 and the following discharge period of March 2007. This sampling was done during a high recharge event after a dry period. At the beginning of the recharge period, diluted $\mathrm{Cl}^{-}$concentrations reflect the infiltration of highly diluted rainwater through preferential flow path in the vadose zone. The dilution is observed on $\mathrm{Cl}^{-}$ down to $10 \mathrm{~m}$. As a consequence, vertical $\mathrm{Cl}^{-}$concentrations in groundwater reflect a mixing between permanent groundwater (35mg/l) and rainwater (about 10mg/l; Figure 8B).

In Kerrien catchment, as the "old" permanent groundwater have similar CFC-11 mixing ratio than the atmosphere at the date of sampling (249pptv; Figure 8A), mixing of permanent groundwater with rainwater should lead to a vertical homogeneous CFC-11 concentration close to the atmospheric concentration (Figure 8A). Instead, CFC-11 concentrations show lower value with a sharp decrease between 6 and $8 \mathrm{~m}$ depth. The depleted values most probably reflect CFC-11 degradation as described in several studies for groundwater with anaerobic conditions (Cook et al., 2006, 1995; Darling et al., 2012; IAEA, 2006; Oster et al., 1996). This hypothesis is reinforced by the low DO values measured for sampling in January $2007(4.5 \mathrm{mg} / \mathrm{l})$. The maximum degradation is observed at 6-8 $\mathrm{m}$ depth which corresponds to the water table level during low flow. This observation is in good agreement with previous study that mentioned a denitrification zone down to $10 \mathrm{~m}$ in Kerrien catchment (Legout et al., 2005; Martin et al., 2006). 
Before recharge, during low flow period, groundwater level is below $7 \mathrm{~m}$ depth. In the fluctuation zone, it is assumed that residual matrix water undergoes a chloride enrichment and CFC-11 degradation. During recharge, as water level rise in the fluctuation zone, permanent groundwater mixes with residual matrix water enriched in $\mathrm{Cl}^{-}$and SF6 and depleted in CFC-11. In the same time, major infiltration of rainwater induces a decrease of $\mathrm{Cl}^{-}$and limits the influence of CFC-11 degradation at shallow depth.

The major dilution effect on $\mathrm{Cl}^{-}$down to $6 \mathrm{~m}$ reflects preferential flow paths and thus the heterogeneity of the aquifer. The contribution of the matrix water is supported by the increase of $\mathrm{SF}_{6}$ values (up to 11.4pptv at $10 \mathrm{~m}$ vs $6.3 \mathrm{pptv}$ in the atmosphere in 2007). These $\mathrm{SF}_{6}$ values in groundwater above atmospheric maximum reveal in situ production and confirm contribution of pore water with a higher contact time. Similar processes occur for the recharge event of December 2008 but to a less extent probably due to a lower water level rise during December 2008. Moreover the dry conditions during the 2 years before January 2007 are supposed to have enhanced the CFC-11 degradation process leading to undatable water samples.

At the end of recharge, (March07 or Apr09), vertical rainwater contribution has stopped as well as CFC11 degradation since the system has been re-oxygenated. Shallow piezometers show high $\mathrm{Cl}^{-}$ concentrations. A decreasing influence of matrix contribution with depth explains the vertical $\mathrm{Cl}^{-}$profile in nest $\mathrm{H}$. During this recession period, except at 5-6m depth, CFC ages can be estimated using a piston flow model (Figure 6). CFC-11 profile shows a downward evolution with a modern value at the top of permanent saturated zone and an older value at the bottom in good agreement with the ${ }^{3} \mathrm{H} /{ }^{3} \mathrm{He}$ age profile. Similar results were obtained for April 2009. Such evolution indicates that mixing with matrix water occurs mainly at shallow depth down to 6-8m, and then horizontal flows dominate in the system.

This interpretation is strengthened by the NGT and EA computation (Figure 3). At the end of the recharge process, when $\mathrm{Cl}^{-}$concentration is the highest, groundwater is characterized by relatively high NGT and lower EA. Such evolution in water chemistry can be explained by the contribution of pore water from the soil and the vadose zone. Although the potential mechanism remains unclear, such pore water closely bounded to the rock matrix would exclude air inclusion. During the beginning of the recharge process, 
most of the NGT show low value below $12^{\circ} \mathrm{C}$ associated to relatively high EA which could reflect the rapid increase of water table due to the by-pass of "cold" rainwater.

\section{Estimation of contribution from the different end-member:}

To validate the processes previously described, we did a first calculation using a 3 end-members mixing model: permanent groundwater, pore water and rainwater (Table 2). For rainwater, we used the atmospheric value of $\mathrm{CFC}-11$ in 2007 and measured $\mathrm{Cl}^{-}$value. For the permanent groundwater, we use CFC-11 value of $\mathrm{F}$ and $\mathrm{Cl}^{-}$values in $\mathrm{H} 15$ during March 2007. The highest measured $\mathrm{Cl}^{-}$concentration (49.4mg/l in H6) was assumed to represent the $\mathrm{Cl}^{-}$concentration in matrix water. Then we assumed a total degradation of CFC-11 leading to value close to 0pptv.

The observed $\mathrm{Cl}^{-}$and CFC-11 values at $6 \mathrm{~m}$ were well simulated. During recharge period, a similar contribution of permanent groundwater and rainwater is found of about $40 \%$. Matrix contribution is estimated to be up to $15 \%$. At the end of recharge, rainwater contribution falls to 0 . Shallow piezometers show high $\mathrm{Cl}^{-}$concentrations that can be reproduced assuming a contribution of $50 \%$ of matrix water to permanent groundwater. Although, this computation can be only considered as a rough estimate, it confirms the influence of pore water contribution and indicates that vertical transfer are not negligible in the upper 6-8 of the groundwater section. A specific modeling should be carried out to further investigate the amplitude of this mechanism and potential effect in larger aquifers.

This interpretation shows that $i$ ) CFCs do not show a constant evolution during the hydrologic cycle and ii) different conceptual flow models have to be considered depending on depth and sampling period. During recharge, vertical flow and mixing dominate, limiting the use of apparent ages. In contrast, during recession periods, horizontal flows dominate and ages can be derived from piston classical flow models. At greater depth (20m), tracer ages are obtained using exponential model showing that horizontal flows dominate and recharge event has low influence. This is consistent with previous results in similar context where the decrease in apparent ages below $10 \mathrm{~m}$ was attributed to groundwater moving horizontally through a second flow system (Cook et al., 1996). As a consequence, in such systems, the use of these 
classical models to estimate groundwater ages from atmospheric tracers should be limited to recession periods. This long-term monitoring shows that a good confidence can be given to apparent age at this period, with a difference of $2.8 \mathrm{yrs}(+/-2.9)$ for the 8-10 m depth interval for 3 samplings with similar hydrological conditions (March07, Apr09 and March10). It is worth noting that the impact of the recharge period tends to disappear rapidly.

\subsection{Temporal distribution of Mean Residence Time}

In the previous sections, we mainly focused on one hydrological cycle to understand groundwater mechanisms. Here we examine the tracer ages obtained at each depth for all the investigated period (Figure 9). Recharge samples (Jan07 and Dec08) presenting CFCs degradation were not used here. A general increase of MRT with depth is observed. It corresponds to an overall vertical groundwater velocity of 0.5 to $0.7 \mathrm{~m}$ per year, which is in good agreement with values obtained from previous tracing experiments in this system (Legout et al., 2007) and studies in similar geological context (Cook et al., 1996). However, a vertical layering of the groundwater MRTs is observed (Figure 9). In the 0 to $6 \mathrm{~m}$ depth piezometers, i.e. within the water table fluctuation zone, very short to a few years MRT are observed. In the 8 to $10 \mathrm{~m}$ depth piezometers, the MRT range from a few years to a decade, while they increase to 10 to 15 years in the 15 to $20 \mathrm{~m}$ depth piezometers. This layering corresponds to the $\mathrm{Cl}^{-}$vertical profile which shows a decreasing variability of concentration with depth (Rouxel et al., 2011).

The long term monitoring showed the effect of annual recharge on the residence time of the groundwater.

Present water only appears just after recharge periods very close to the water table. During the recession periods, even at the water table surface, the MRT is already close to 2.5 years (March05, Apr09) and water shows high $\mathrm{Cl}^{-}$concentrations which confirms the influence of long-term residence time pore water from the unsaturated zone. At $8-10 \mathrm{~m}$ during the dry period (2005-2006 cycle), we show that groundwater is rejuvenated as water level increases. During recession, residence time tends to increase up to about 12 years as less rainwater enters in the system. The January 2007 special event highly modifies the system since a high amount of young water enters the system. In consequence, during the humid period, MRT are 
much younger with a mean value about 5yrs. At $15 \mathrm{~m}$ depth the MRTs are more stable than above. However the influence of the strong recharge event of January 2007 can still be observed: residence time is about 1012yrs before January but decreases after January and stabilizes at 8yrs during 2008 and 2009 cycles.

At 20m, during the dry period, a slight increase of residence time is observed in relation with a slight $\mathrm{Cl}^{-}$ increase. Then, residence times decrease from June 2007 to April 2009 and stabilize at 8yrs indicating that young water rejuvenates slowly the system at this depth. This rejuvenation explains the observed decrease of $\mathrm{Cl}^{-}$concentration since January 2007 (Figure 2). This observation confirm that groundwater at 20m behaves relatively independently from other depths.

\subsection{Consequences for conceptual model of the catchment}

The highly similar pattern observed for both $\mathrm{CFCs}$ and $\mathrm{Cl}^{-}$concentrations and the synchronous variations during recharge at depth of 5 to $15 \mathrm{~m}$ highlight the occurrence of vertical transfer from the variably saturated zone (2 -6m) down to 10-15m depth. These results contradict the usual consideration of a major horizontal transfer from up to downslope as assumed by the approximation of Dupuit-Forsheimer which neglects vertical flows. These results also confirm that a double flow system can explain temporal variation in anionic concentrations as suggested previously (Legout et al., 2007; Rouxel et al., 2011). In addition, this work gives a better understanding of the mechanism controlling recharges. Local vertical downward flows occur during high recharge period inducing temporal variability in the anionic concentration of the permanent groundwater. High CFC-11 degradation at shallow depth (and CFC-12 to a lesser extent) indicates that during infiltration, rainwater mixes with evolved water from the matrix. As contribution of rainwater decreases, evolved matrix water contribution increases leading to $\mathrm{Cl}^{-}$increase. This phenomenon is observed only when a sufficient groundwater level is reached and is enhanced by previous dry conditions. 


\section{Conclusions}

Using a detailed analysis of long-term time-series of dissolved gas tracers in a shallow aquifer, we investigated how tracer concentrations and associated residence times evolve with depth and which flow processes (by-pass/ PFM/EM/Mixing) explain these evolutions. The long-term monitoring of dissolved gases shows a good repeatability in the permanent saturated zone and more variable apparent ages in the water fluctuation zone dominated by mixing. $\mathrm{CFCs}$ and ${ }^{3} \mathrm{H} /{ }^{3} \mathrm{He}$ indicate young groundwater. $\mathrm{SF}_{6}$ show concentrations above the mean atmospheric mixing ratio indicating lithological production which limits its utilization in this aquifer for groundwater dating.

In this study, we show that hydrologic conditions have more influence on dissolved gas concentration than the location along the hillslope. Two different flow processes have to be considered between recharge and recession periods. During water table decreases, CFC-11 vertical profiles are highly homogeneous. During recharge periods, CFC profiles show variable but lower CFCs values reflecting contribution of modern rainwater and of the weathered matrix with variable proportion at the beginning of recharge and at the end of recharge period. This conceptual model is consistent with $\mathrm{Cl}^{-}$concentration as well as excess air and recharge temperature evolution during the hydrologic cycle. The small variations observed between the sampling periods during recessions show that a single field sampling during groundwater recession period can be sufficient in most cases to estimate MRT. A general increase of mean residence time with depth is observed at longer time scales. In addition, this study shows a clear stratification between the first meters below the water table which exhibit highly variable gas concentrations, and the deep part of the aquifer which is much more homogeneous. Such stratification indicates that hydrological processes strongly differ in the variably saturated zone which acts as a buffer. These results confirm the interest of CFCs as age dating tracers for shallow groundwater, but also as natural tracers to conceptualizing flow processes. In this way, this work confirms the interest of atmospheric tracers to better constrain conceptual hydrological models regarding to their ability to represent different processes according to the hydrological period. Finally, this work demonstrates the 
interest of long-term monitoring of dissolved gases in complex hydrogeological environment for a better understanding of the recharge processes, with specific recharge events that impact groundwater over several cycles.

\section{Acknowledgements}

This work received a financial support by the French National Research Agency (ANR) through the Systerra programme (Acassya project ANR-08-STRA-01), the EU-RDF INTERREG IVA France (Channel) - England programme (Climawat project), and the INSU-CNRS EC2CO programme (Aquadiv project). The investigations also benefited from the support of INRA and CNRS (Environmental Research Observatory AgrHys). 


\section{References}

Aeschbach-Hertig, W., 2004. Excess air in groundwater: problems and opportunities. Annual Meeting of GSA, Denver.

Aeschbach-Hertig, W., Peeters, F., Beyerle, U., Kipfer, R., 2000. Palaeotemperature reconstruction from noble gases in ground water taking into account equilibration with entrapped air. Nature 405, 1040 1044.

Aquilina, L., de Montety, V., Labasque, T., Molénat, J., Ruiz, L., Ayraud-Vergnaud, V., Fourré, E., 2010. CFC and SF6 concentrations in shallow groundwater: implications for groundwater age determination. WRI-13, Guanajuato, 16-20 Août 2010. Water-Rock Interaction XIII proceedings.

Aquilina, L., Vergnaud-Ayraud, V., Labasque, T., Bour, O., Molenat, J., Ruiz, L., de Montety, V., De Ridder, J., Roques, C., Longuevergne, L., 2012. Nitrate dynamics in agricultural catchments deduced from groundwater dating and long-term nitrate monitoring in surface- and groundwaters. Sci. Total Environ. 435-436, 167-178. doi:10.1016/j.scitotenv.2012.06.028

Ayraud, V., Aquilina, L., Labasque, T., Pauwels, H., Molenat, J., Pierson-Wickmann, A.-C., Durand, V., Bour, O., Tarits, C., Le Corre, P., Fourre, E., Merot, P., Davy, P., 2008. Compartmentalization of physical and chemical properties in hard-rock aquifers deduced from chemical and groundwater age analyses. Appl. Geochem. 23, 2686-2707. doi:10.1016/j.apgeochem.2008.06.001

Basu, N.B., Jindal, P., Schilling, K.E., Wolter, C.F., Takle, E.S., 2012. Evaluation of analytical and numerical approaches for the estimation of groundwater travel time distribution. J. Hydrol. 475, 6573. doi:10.1016/j.jhydrol.2012.08.052

Böhlke, J.-K., 2002. Groundwater recharge and agricultural contamination. Hydrogeol. J. 10, 153-179. doi:10.1007/s10040-001-0183-3

Böhlke, J.K., Denver, J.M., 1995. Combined Use of Groundwater Dating, Chemical, and Isotopic Analyses to Resolve the History and Fate of Nitrate Contamination in Two Agricultural Watersheds, Atlantic Coastal Plain, Maryland. Water Resour. Res. 31, 2319-2339. doi:10.1029/95wr01584

Chatton, E., Aquilina, L., Pételet-Giraud, E., Cary, L., Bertrand, G., Labasque, T., Hirata, R., Martins, V., Montenegro, S., Vergnaud, V., Aurouet, A., Kloppmann, W., Pauwels, 2016. Glacial recharge, salinisation and anthropogenic contamination in the coastal aquifers of Recife (Brazil). Sci. Total Environ. 569-570, 1114-1125. doi:10.1016/j.scitotenv.2016.06.180

Cook, P.G., Plummer, L., Solomon, D., Busenberg, E., Han, L., 2006. Effects and processes that can modify apparent CFC age, in: Use of Chloroflurocarbons in Hydrology: A Guidebook. IAEA, Vienna, pp. 31-58.

Cook, P.G., Solomon, D.K., Plummer, L.N., Busenberg, E., Schiff, S.L., 1995. Chlorofluorocarbons as Tracers of Groundwater Transport Processes in a Shallow, Silty Sand Aquifer. Water Resour. Res. 31, 425-434. doi:10.1029/94WR02528

Cook, P.G., Solomon, D.K., Sanford, W.E., Busenberg, E., Plummer, L.N., Poreda, R.J., 1996. Inferring shallow groundwater flow in saprolite and fractured rock using environmental tracers. Water Resour Res 32,1501-1509. doi:10.1029/96wr00354

Creed, I.F., Band, L.E., 1998. Export of nitrogen from catchments within a temperate forest: Evidence for a unifying mechanism regulated by variable source area dynamics. Water Resour. Res. 34, 3105-3120. doi:10.1029/98wr01924

Darling, W.G., Gooddy, D.C., MacDonald, A.M., Morris, B.L., 2012. The practicalities of using CFCs and SF6 for groundwater dating and tracing. Appl. Geochem. 27, 1688-1697. doi:10.1016/j.apgeochem.2012.02.005

Delbart, C., Barbecot, F., Valdes, D., Tognelli, A., Fourre, E., Purtschert, R., Couchoux, L., JeanBaptiste, P., 2016. Investigation of young water inflow in karst aquifers using SF6-CFC-3H/He-85Kr39Ar and stable isotope components. Appl. Geochem. 50, 164-176. doi:10.1016/j.apgeochem.2014.01.011 
Fovet, O., Ruiz, L., Faucheux, M., Molénat, J., Sekhar, M., Vertes, F., Aquilina, L., Gascuel-Odoux, C., Durand, P., 2015. Using long time series of agricultural-derived nitrates for estimating catchment transit times. J. Hydrol. 522, 603-617. doi:10.1016/j.jhydrol.2015.01.030

Gooddy, D.C., Darling, W.G., Abesser, C., Lapworth, D.J., 2006. Using chlorofluorocarbons (CFCs) and sulphur hexafluoride (SF6) to characterise groundwater movement and residence time in a lowland Chalk catchment. J. Hydrol. 330, 44-52. doi:10.1016/j.jhydrol.2006.04.011

Hall, C.M., Castro, M.C., Lohmann, K.C., Ma, L., 2005. Noble gases and stable isotopes in a shallow aquifer in southern Michigan: Implications for noble gas paleotemperature reconstructions for cool climates. Geophys. Res. Lett. 32, L18404. doi:10.1029/2005GL023582

Han, L.E., Groning, M., Plummer, L.N., Solomon, D.K., 2006. Comparison of the CFC technique with other techniques $(3 \mathrm{H}, 3 \mathrm{H} / 3 \mathrm{He}, 85 \mathrm{Kr})$, in: Use of Chlorofluorocarbons in Hydrology: A Guidebook. IAEA, pp. 191-198.

Happell, J.D., Opsahl, S., Top, Z., Chanton, J.P., 2006. Apparent CFC and 3H/3He age differences in water from Floridan Aquifer springs. J. Hydrol. 319, 410-426.

Heaton, T.H.E., Vogel, J.C., 1981. "Excess air" in groundwater. J. Hydrol. 50, 201-216. doi:10.1016/0022-1694(81)90070-6

Herzberg, O., Mazor, E., 1979. Hydrological applications of noble gases and temperature measurements in underground water systems: Examples from Israel. J. Hydrol. 41, 217-231. doi:10.1016/00221694(79)90063-5

Hrachowitz, M., Savenije, H.H.G., Blöschl, G., McDonnell, J.J., Sivapalan, M., Pomeroy, J.W., Arheimer, B., Blume, T., Clark, M.P., Ehret, U., Fenicia, F., Freer, J.E., Gelfan, A., Gupta, H.V., Hughes, D.A., Hut, R.W., Montanari, A., Pande, S., Tetzlaff, D., Troch, P.A., Uhlenbrook, S., Wagener, T., Winsemius, H.C., Woods, R.A., Zehe, E., Cudennec, C., 2013. A decade of Predictions in Ungauged Basins (PUB) - a review. Hydrol. Sci. J. 58, 1-58. doi:10.1080/02626667.2013.803183

IAEA, 2006. Use of Chlorofluorocarbons in hydrology: A Guidebook, STI/PUB/1238. <http://wwwpub.iaea.org/MTCD/publications/PDF/Pub1238_web.pdf $>$.

Jean-Baptiste, P., Fourré, E., Dapoigny, A., Baumier, D., Baglan, N., Alanic, G., 2010. 3He mass spectrometry for very low-level measurement of organic tritium in environmental samples. J Env. Rad 101, 185-190.

Jean-Baptiste, P., Mantisi, F., Dapoigny, A., Stievenard, M., 1992. Design and performance of a mass spectrometric facility for measuring helium isotopes in natural waters and for low-level tritium determination by the 3He ingrowth method. Appl Radiat Isot 43, 881-891.

Kaown, D., Koh, D.-C., Lee, K.-K., 2009. Effects of groundwater residence time and recharge rate on nitrate contamination deduced from $\delta 18 \mathrm{O}, \delta \mathrm{D}, 3 \mathrm{H} / 3 \mathrm{He}$ and CFCs in a small agricultural area in Chuncheon, Korea. J. Hydrol. 366, 101-111. doi:10.1016/j.jhydrol.2008.12.016

Katz, B.G., Böhlke, J.K., Hornsby, H.D., 2001. Timescales for nitrate contamination of spring waters, northern Florida, USA. Chem. Geol. 179, 167-186. doi:10.1016/s0009-2541(01)00321-7

Kendall, C., McDonnell, J.J., 1998. Isotope Tracers in Catchment Hydrology. Elsevier Science Publishers, Amsterdam.

Kipfer, R., Aeschbach-Hertig, W., Peeters, F., \& Stute, M. (2002). Noble gases in lakes and ground waters. Reviews in mineralogy and geochemistry, 47(1), 615-700.

Kirchner, J.W., Feng, X., Neal, C., 2001. Catchment-scale advection and dispersion as a mechanism for fractal scaling in stream tracer concentrations. J. Hydrol. 254, 82-101. doi:10.1016/S00221694(01)00487-5

Koh, D.-C., Niel Plummer, L., Kip Solomon, D., Busenberg, E., Kim, Y.-J., Chang, H.-W., 2006. Application of environmental tracers to mixing, evolution, and nitrate contamination of ground water in Jeju Island, Korea. J. Hydrol. 327, 258-275. doi:10.1016/j.jhydrol.2005.11.021

Kolbe, T., Marçais, J., Thomas, Z., Abbott, B.W., de Dreuzy, J.-R., Rousseau-Gueutin, P., Aquilina, L., Labasque, T., Pinay, G., 2016. Coupling 3D groundwater modeling with CFC-based age dating to classify local groundwater circulation in an unconfined crystalline aquifer. J. Hydrol. 543, Part A, 3146. doi:10.1016/j.jhydrol.2016.05.020 
Labasque, T., Vergnaud, V. and Aquilina, L., 2008. Recent methodology developed in Rennes (France) at Geosciences laboratory in groundwater dating using CFCs, SF6 and dissolved gases (Ne, Ar, O2, N2, $\mathrm{CH} 4, \mathrm{CO} 2$ and N2O). G-DAT 2008 proceedings, Leipzig, Germany.

Le Gal La Salle, C., Aquilina, L., Fourre, E., Jean-Baptiste, P., Michelot, J.L., Roux, C., Bugai, D., Labasque, T., Simonucci, C., Van Meir, N., Noret, A., Bassot, S., Dapoigny, A., Baumier, D., Verdoux, P., Stammose, D., Lancelot, J., 2012. Groundwater residence time downgradient of Trench No. 22 at the Chernobyl Pilot Site: Constraints on hydrogeological aquifer functioning. Appl. Geochem. 27, 1304-1319. doi:10.1016/j.apgeochem.2011.12.006

Legout, C., Molenat, J., Aquilina, L., Gascuel-Odoux, C., Faucheux, M., Fauvel, Y., Bariac, T., 2007. Solute transfer in the unsaturated zone-groundwater continuum of a headwater catchment. J. Hydrol. 332, 427-441.

Legout, C., Molenat, J., Lefebvre, S., Marmonier, P., Aquilina, L., 2005. Investigation of biogeochemical activities in the soil and unsaturated zone of weathered granite. Biogeochemistry 75, 329-350.

Maloszewski, P., Zuber, A., 1982. Determining the turnover time of groundwater systems with the aid of environmental tracers. J. Hydrol. 57, 207-231. doi:10.1016/0022-1694(82)90147-0

Martin, C., Aquilina, L., Gascuel-Odoux, C., Molénat, J., Faucheux, M., Ruiz, L., 2004. Seasonal and interannual variations of nitrate and chloride in stream waters related to spatial and temporal patterns of groundwater concentrations in agricultural catchments. Hydrol. Process. 18, 1237-1254. doi:10.1002/hyp.1395

Martin, C., Molenat, J., Gascuel-Odoux, C., Vouillamoz, J.M., Robain, H., Ruiz, L., Faucheux, M., Aquilina, L., 2006. Modelling the effect of physical and chemical characteristics of shallow aquifers on water and nitrate transport in small agricultural catchments. J. Hydrol. 326, 25-42. doi:10.1016/j.jhydrol.2005.10.040

Martin, J.B., Kurz, M.J., Khadka, M.B., 2016. Climate control of decadal-scale increases in apparent ages of eogenetic karst spring water. J. Hydrol. 540, 988-1001. doi:10.1016/j.jhydrol.2016.07.010

Molénat, J., Davy, P., Gascuel-Odoux, C., Durand, P., 2000. Spectral and cross-spectral analysis of three hydrological systems. Phys. Chem. Earth Part B Hydrol. Oceans Atmosphere 25, 391-397. doi:10.1016/S1464-1909(00)00032-0

Molenat, J., Durand, P., Gascuel-Odoux, C., Davy, P., Gruau, G., 2002. Mechanisms of Nitrate Transfer from Soil to Stream in an Agricultural Watershed of French Brittany. Water. Air. Soil Pollut. 133, 161-183. doi:10.1023/a:1012903626192

Molénat, J., Gascuel-Odoux, C., 2002. Modelling flow and nitrate transport in groundwater for the prediction of water travel times and of consequences of land use evolution on water quality. Hydrol. Process. 16, 479-492. doi:10.1002/hyp.328

Molénat, J., Gascuel-Odoux, C., Aquilina, L., Ruiz, L., 2013. Use of gaseous tracers (CFCs and SF6) and transit-time distribution spectrum to validate a shallow groundwater transport model. J. Hydrol. 480, 1-9. doi:10.1016/j.jhydrol.2012.11.043

Molenat, J., Gascuel-Odoux, C., Ruiz, L., Gruau, G., 2008. Role of water table dynamics on stream nitrate export and concentration in agricultural headwater catchment (France). J. Hydrol. 348, 363378. doi:10.1016/j.jhydrol.2007.10.005

Neal, C., Kirchner, J.W., 2000. Sodium and chloride levels in rainfall, mist, streamwater and groundwater at the Plynlimon catchments, mid-Wales: inferences on hydrological and chemical controls. Hydrol. Earth Syst. Sci. 295.

Newman, B.D., Osenbrück, K., Aeschbach-Hertig, W., Kip Solomon, D., Cook, P., Różański, K., Kipfer, R., 2010. Dating of 'young' groundwaters using environmental tracers: advantages, applications, and research needs. Isotopes Environ. Health Stud. 46, 259-278. doi:10.1080/10256016.2010.514339

Oster, H., Sonntag, C., Münnich, K.O., 1996. Groundwater age dating with chlorofluorocarbons. Water Resour Res 32, 2989-3001. doi:10.1029/96wr01775

Rademacher, L.K., Clark, J.F., Hudson, G.B., Erman, D.C., Erman, N.A., 2001. Chemical evolution of shallow groundwater as recorded by springs, Sagehen basin; Nevada County, California. Chem. Geol. 179, 37-51. doi:10.1016/S0009-2541(01)00314-X 
Rouxel, M., Molénat, J., Ruiz, L., Legout, C., Faucheux, M., Gascuel-Odoux, C., 2011. Seasonal and spatial variation in groundwater quality along the hillslope of an agricultural research catchment (Western France). Hydrol. Process. 25, 831-841. doi:10.1002/hyp.7862

Rouxel, M., Ruiz, L., Molenat, J., Hamon, Y., Chirie, G., Michot, D., 2012. Experimental Determination of Hydrodynamic Properties of Weathered Granite. Vadose Zone J. 11, 10. doi:10.2136/vzj2011.0076

Ruiz, L., Abiven, S., Durand, P., Martin, C., Vertes, F., Beaujouan, V., 2002a. Effect on nitrate concentration in stream water of agricultural practices in small catchments in Brittany: I. Annual nitrogen budgets. Hydrol. Earth Syst. Sci. 497.

Ruiz, L., Abiven, S., Martin, C., Durand, P., Beaujouan, V., Molénat, J., 2002b. Effect on nitrate concentration in stream water of agricultural practices in six small catchments in Brittany: II. Temporal variations and mixing processes. Hydrol. Earth Syst. Sci. 6, 507-513.

Schlosser, P., Stute, M., Sonntag, C., \& Münnich, K. O. (1989). Tritiogenic 3He in shallow groundwater. Earth and Planetary Science Letters, 94(3-4), 245-256.

Stute, M., Forster, M., Frischkorn, H., Serejo, A., Clark, J.F., Schlosser, P., Broecker, W.S., Bonani, G., 1995. Cooling of tropical Brazil $\left(5{ }^{\circ} \mathrm{C}\right)$ during the Last Glacial Maximum. Science 269, 379-383. doi:10.1126/science.269.5222.379

Suckow, A., 2014. The age of groundwater : Definitions, models and why we do not need this term. Appl. Geochem. 50, 222-230. doi:10.1016/j.apgeochem.2014.04.016 


\section{Table caption}

Table 1. Number of sample (No), mean values and standard deviation (STDV) obtained for CFC-11, CFC-12, $\mathrm{SF}_{6}$ and ${ }^{3} \mathrm{H} /{ }^{3} \mathrm{He}$, per nest and per depth. For CFCs and SF6, both mixing ratio and apparent tracer ages are given. The relative standard deviation (RSD) is also given for CFCs and $\mathrm{SF}_{6}$.

Table 2. End-members values and their respective contribution in H6 for a recharge period (January 2007) and an end of recharge period (March 2007). 


\section{Figure captions}

Figure 1. (A) Topography of the Kerrien catchment with (B) a schematic view of the transect F, H, J, L and the piezometer nests.

Figure 2. Temporal evolution of precipitation, hydrogeology and hydrochemical parameters $\left(\mathrm{Cl}^{-}, \mathrm{CFC}-11\right.$, SF6) of the system.

(A) Annual precipitation deviation in comparison to the mean interannual precipitation over the year 2005 to 2010; (B) groundwater depth time series from the soil surface at nest $\mathrm{H}$ (upslope), J (midslope) and $\mathrm{L}$ (downslope), precipitation and potential evapotranspiration at the soil surface time series. Sampling periods have been reported on the water level and water level variation in $\mathrm{H}$ (white circle). (C) $\mathrm{Cl}$ concentration (mg. $\mathrm{l}^{-1}$ ) and (D) CFC-11 and SF6 dissolved concentrations (pptv) respectively measured from January 2005 to October 2010 at different depth in nest $\mathrm{H}$ (upslope) and F compared to daily water level variation (in cm.d-1) in H15. (E) SF6 dissolved concentrations (pptv) respectively measured from January 2005 to October 2010 at different depth in nest H (upslope) and F. The dash lines (D-E) show the maximum mixing ratio in the atmosphere (black line) and the present mixing ratio (grey line). Main recharge period have been highlighted in grey.

Figure 3. Recharge temperature and excess air derived from gas concentrations

Figure 4. Vertical profiles of CFC-11 and CFC-12 concentration at nests H (upslope), J (midslope) and L (downslope) (A) and corresponding apparent age evolution (B). Apparent ${ }^{3} \mathrm{H} /{ }^{3} \mathrm{He}$ age vertical profile has also been reported (B). Bars indicate the coefficient of variation between the different sampling.

Figure 5. Comparison of CFC-11 vertical profiles (y-axis unit is $\mathrm{m}$ ) for (A) recharge period; and (B) recession period. Sampling periods with less than 3 depths have not been represented. Dashed line represent equilibrium concentration in 2010; maximum equilibrium concentration is 274pptv (1994). 
Figure 6. Comparison of ${ }^{3} \mathrm{H} /{ }^{3} \mathrm{He}$ and CFC-11 apparent ages at different depths, assuming a piston fow model for CFCs ages (A). Considering the discrepancy at 15-20m, CFC-11 ages have been determined using the best fitted model between EM or PFM and compared to $3 \mathrm{H} / 3 \mathrm{He}$ apparent ages according to depth (B) and the period of sampling (C).

Figure 7. CFC-11 and CFC-12 dissolved concentrations compared to flow models (Piston Flow Model (PFM); Exponential Model (EM) for sampling in 2005, 2007 and 2010; Binary Mixing Model (BMM)) depending on depth of sampling for all transect (A) or only plot H (B) or depending on the hydrological period in plot H: Recharge (C); Recession (D). During recharge, data are scattered below the model line.

Figure 8. CFC-11 (A) and $\mathrm{Cl}^{-}$(B) profile in nest $\mathrm{H}$ during recharge event of January07 and following recession period (March07). Rainwater and permanent groundwater end-member are indicated by rectangles and their mixing by the arrow. Solid black line with crosses show the atmospheric mixing ratio of CFC-11 during the past 20 years.

Figure 9. Time series of ages derived from CFC-11 and $3 \mathrm{H} / 3 \mathrm{He}$ for the unsaturated zone (4-6m) and the permanent groundwater $(8 \mathrm{~m}, 10 \mathrm{~m}, 15 \mathrm{~m}, 20 \mathrm{~m})$. 
A Kerrien catchment

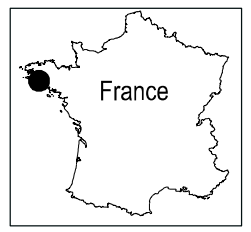

-.. Altitude (m)

- Stream

- Catchment limit

$\square \quad$ Piezometer nest

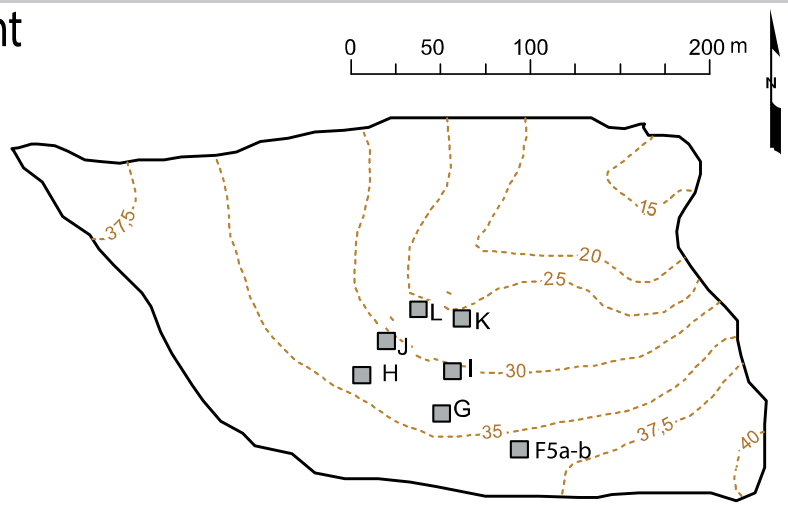

B Schematic view of the transect HJL

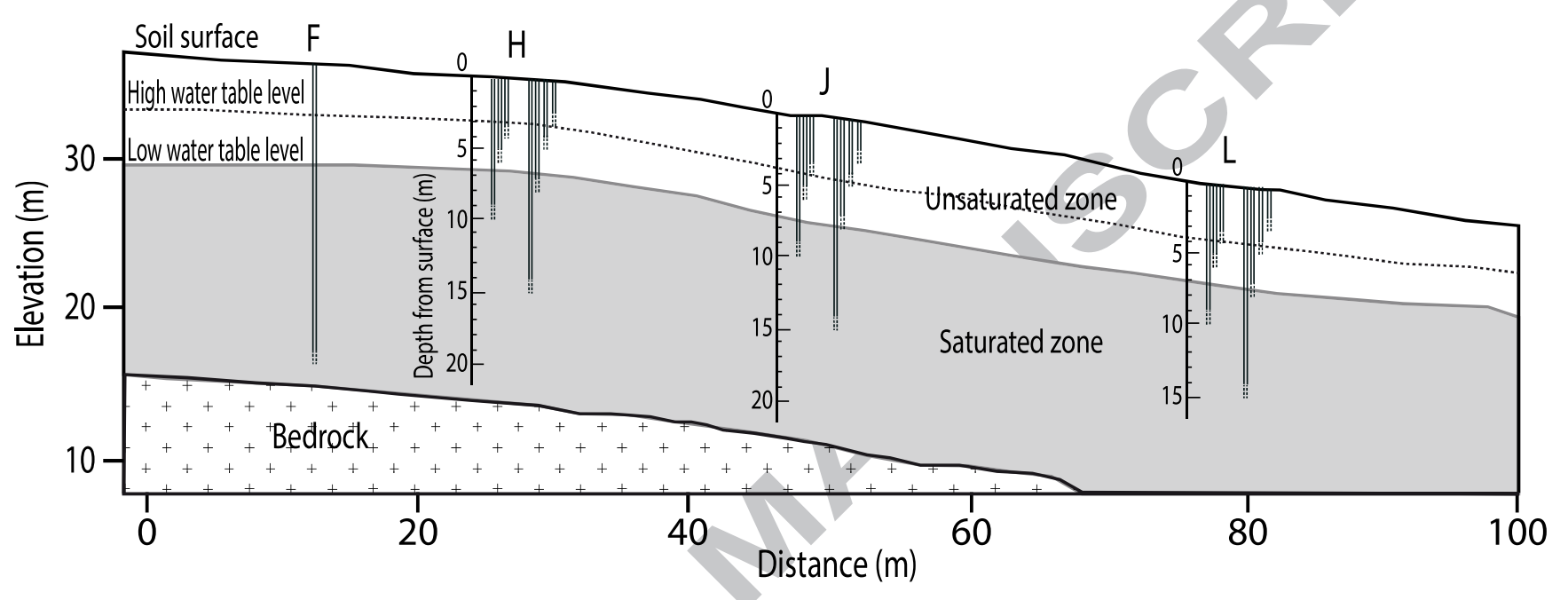




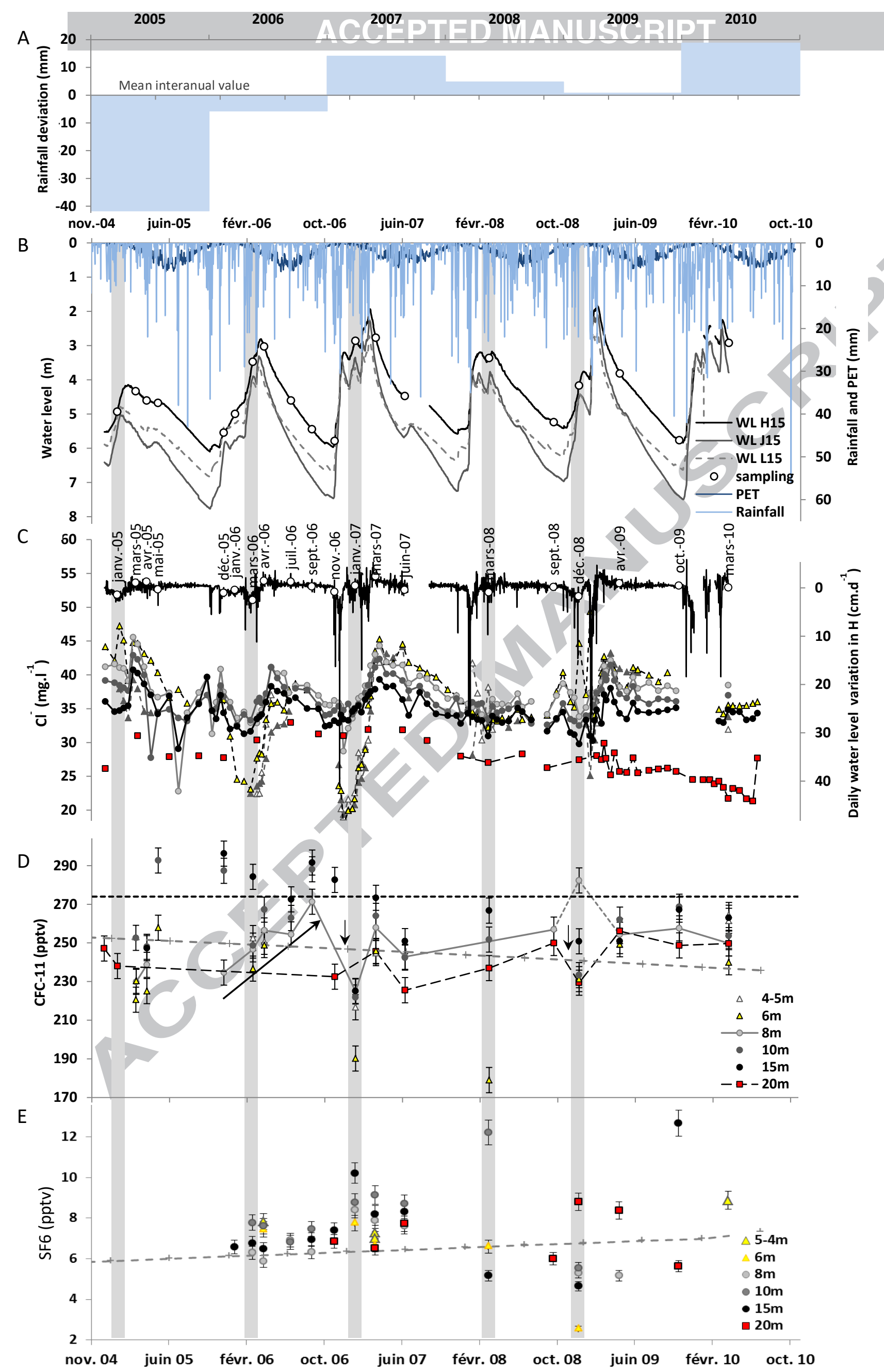




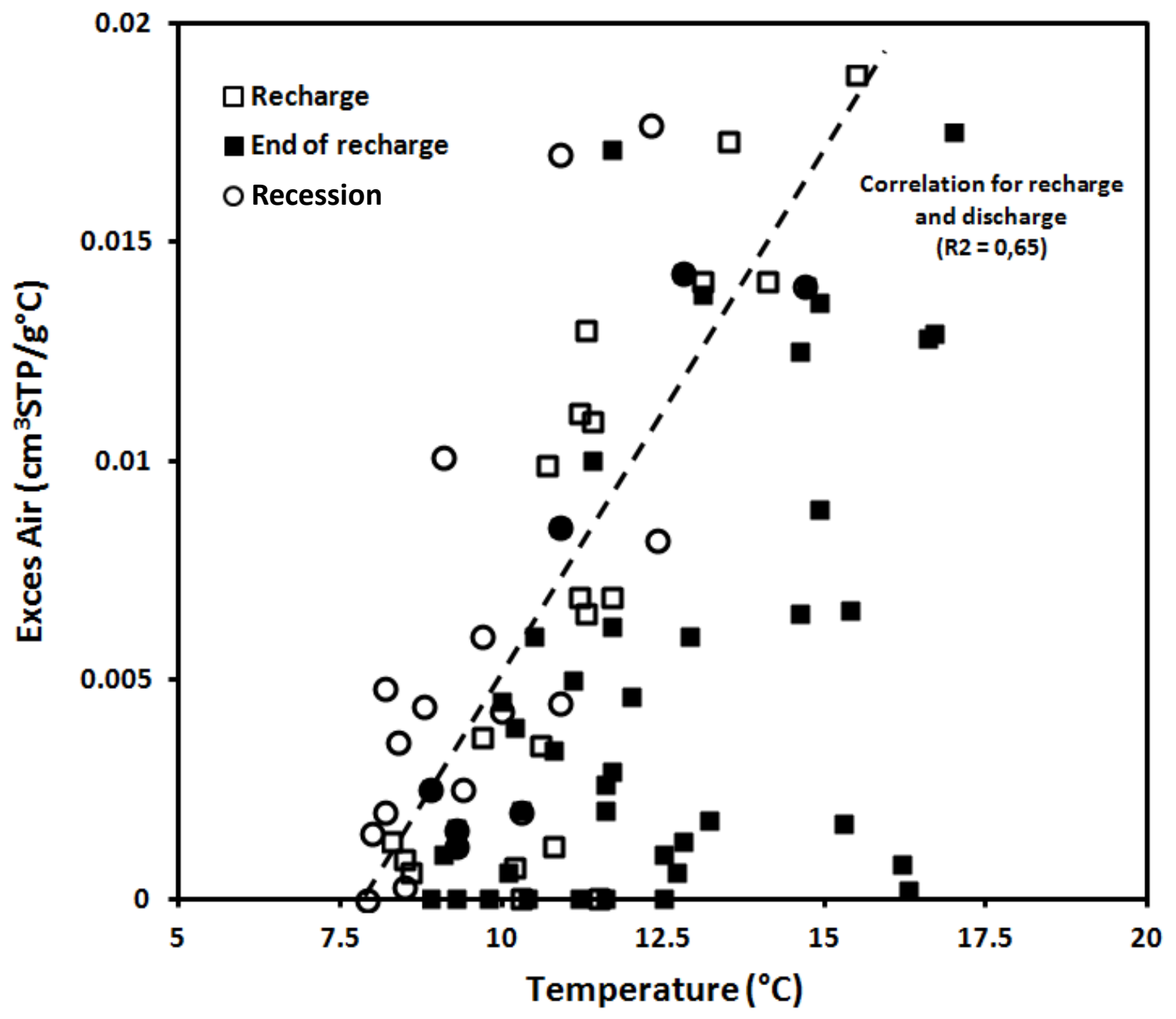




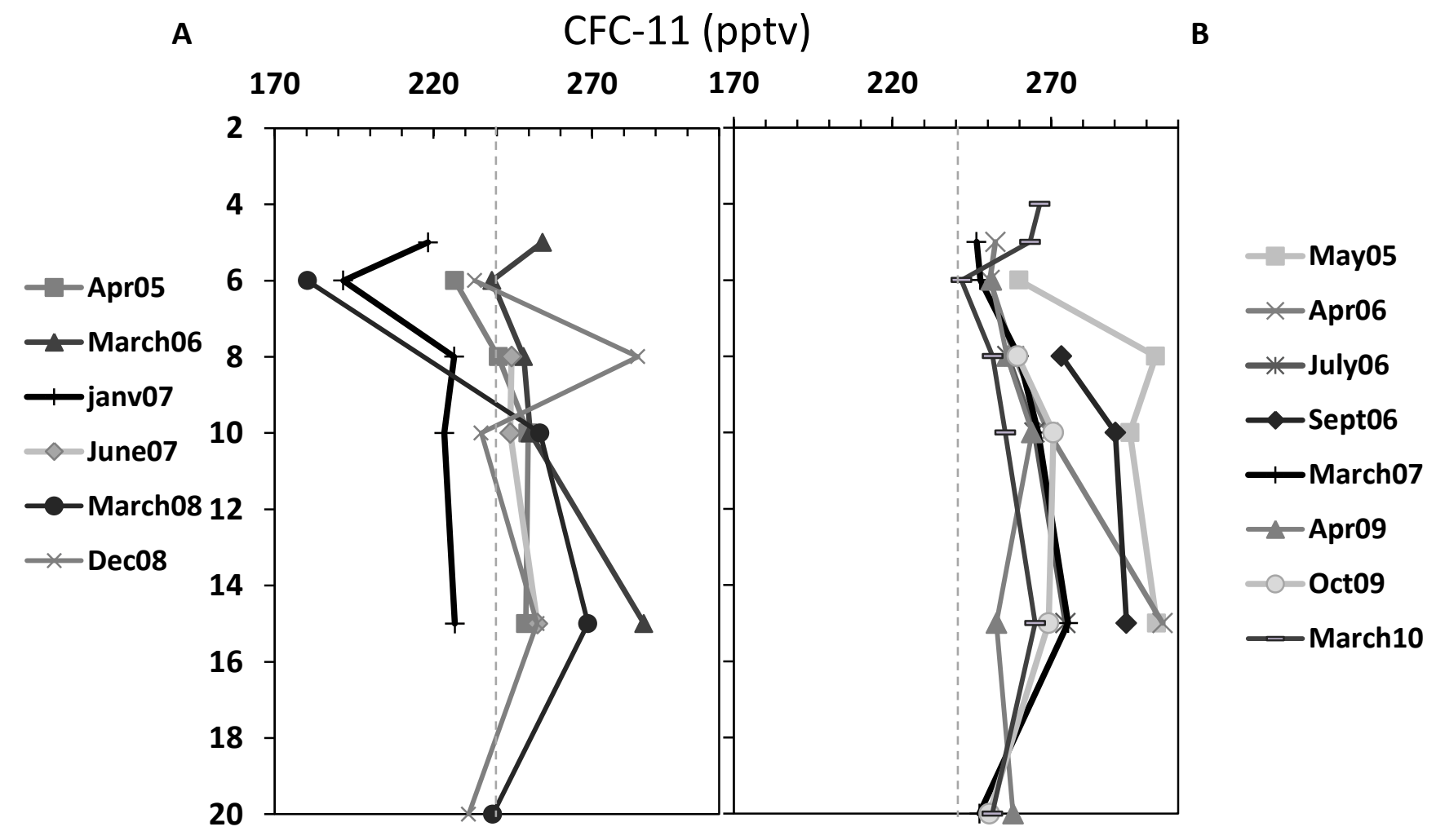



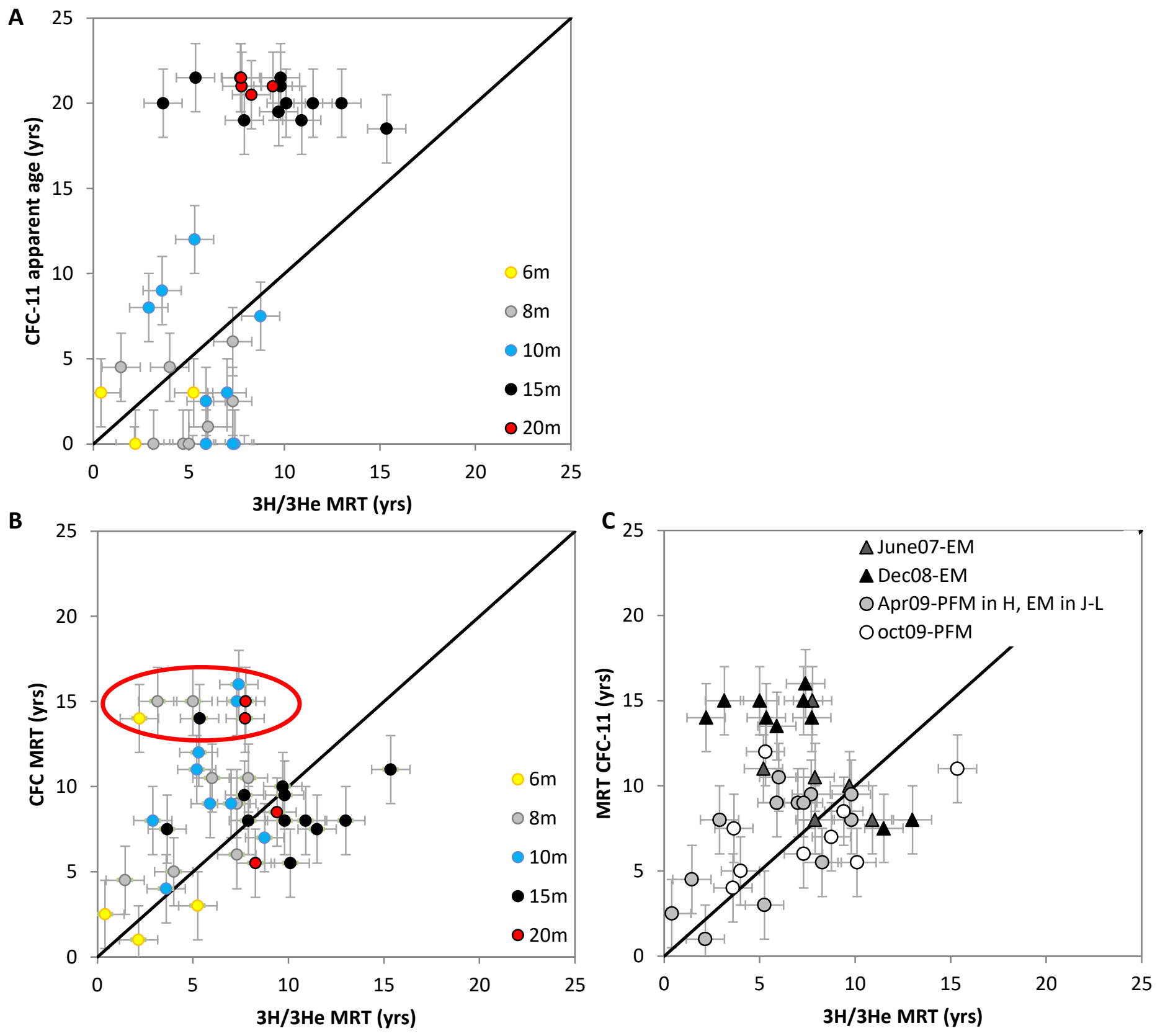

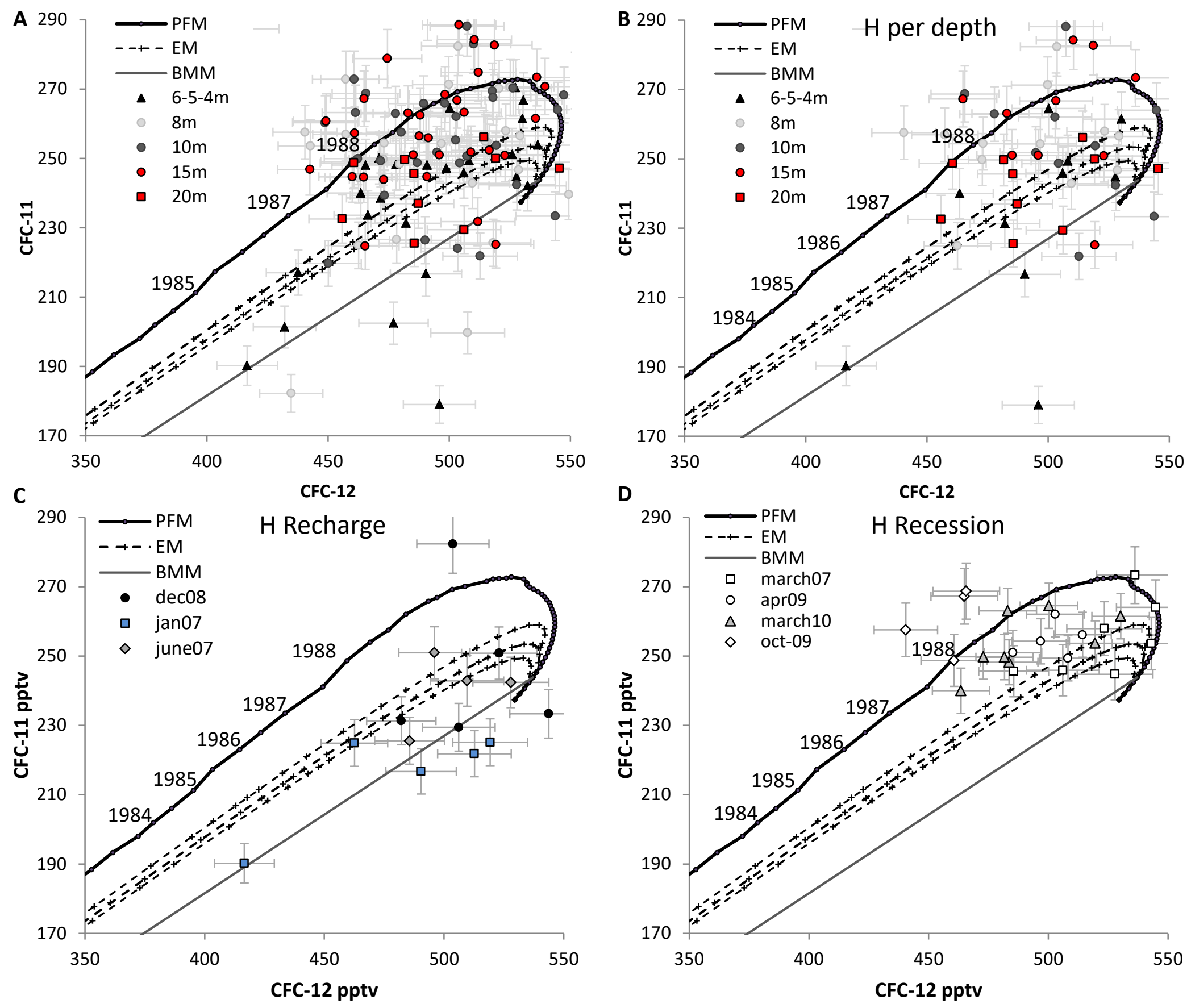


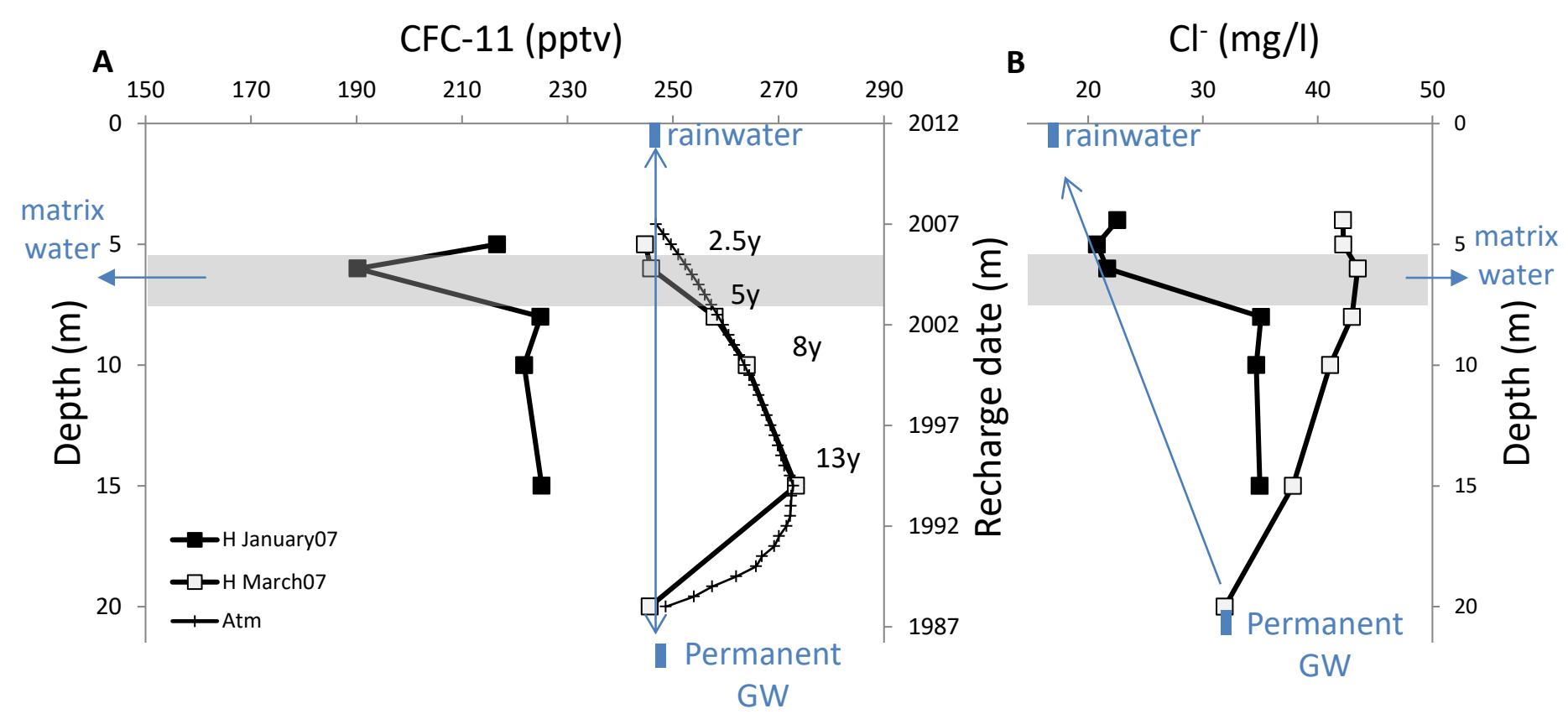




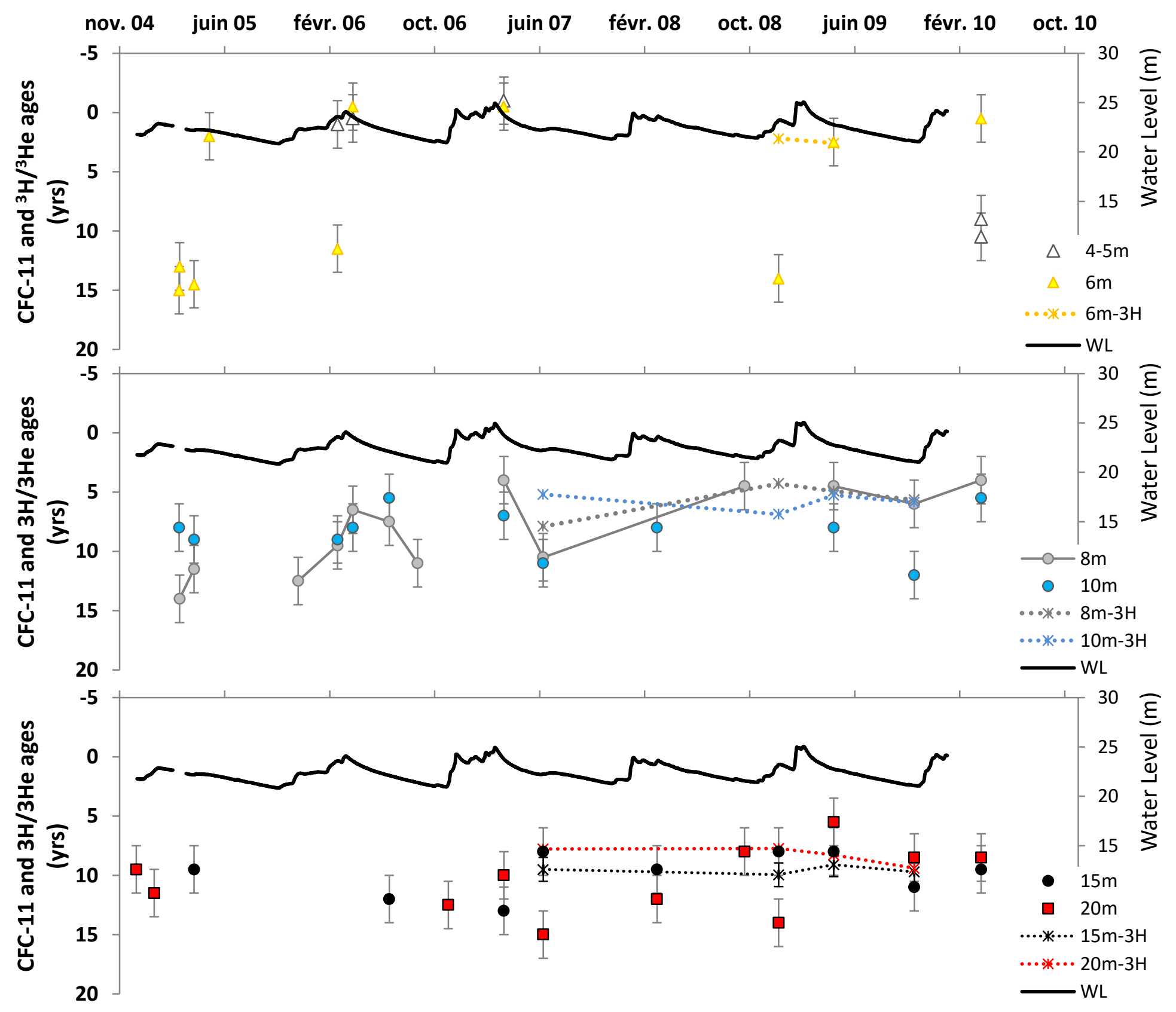




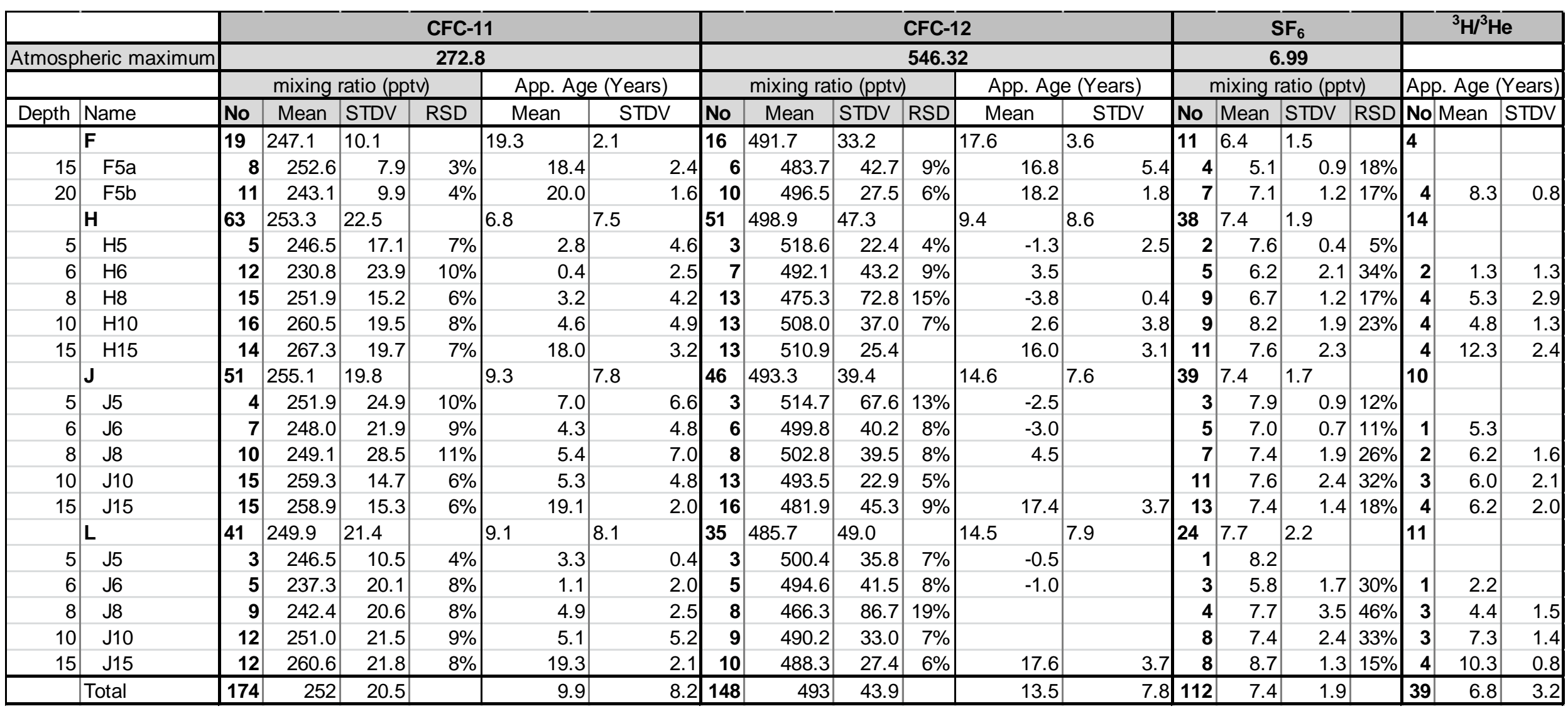




\begin{tabular}{|c|c|c|c|c|c|}
\hline & $\begin{array}{l}\text { Permanent } \\
\text { groundwater }\end{array}$ & $\begin{array}{l}\text { Matrix } \\
\text { Water }\end{array}$ & Rainwates & $\begin{array}{l}\text { H6 } \\
\text { recharge } \\
\text { Jan07 }\end{array}$ & $\begin{array}{l}\text { H6 end of } \\
\text { recharge } \\
\text { March07 }\end{array}$ \\
\hline $\mathrm{Cl}^{-}(\mathrm{mg} / \mathrm{l})$ & 35 & 50 & 8 & 25.1 & 42.5 \\
\hline $\begin{array}{l}\text { CFC-11 } \\
\text { (pptv) }\end{array}$ & 249 & 0 & 247 & 210.75 & 261.5 \\
\hline $\begin{array}{l}\text { Contribution } \\
\text { (Recharge) }\end{array}$ & $40 \%$ & $15 \%$ & $45 \%$ & & \\
\hline Contribution & & & & & \\
\hline $\begin{array}{l}\text { (End of } \\
\text { recharge) }\end{array}$ & $50 \%$ & $50 \%$ & $0 \%$ & & \\
\hline
\end{tabular}


- We analyzed long-term time-series of dissolved gas tracers in groundwater

- We investigated recharge processes through time and depth using CFCs and ${ }^{3} \mathrm{H} /{ }^{3} \mathrm{He}$ according to hydrological conditions

- Different flow processes occur during recharge and recession periods

- Hydrological processes differ between the first meters and the deeper part of the aquifer 